\title{
Revealing morphological characteristics of Goniodorididae genera (Mollusca: Nudibranchia)
}

\author{
Sofia Paz-Sedano ${ }^{1}$ [D $\cdot$ Guillermo Díaz-Agras ${ }^{2} \cdot$ Terrence M. Gosliner $^{3} \cdot$ Marta Pola $^{1,4}$
}

Received: 16 April 2021 / Accepted: 5 August 2021 / Published online: 12 October 2021

(C) The Author(s) 2021

\begin{abstract}
Detailed knowledge of the anatomy of the species is an essential element in taxonomic studies, since it allows the comparison and differentiation of separate groups of taxa. It becomes especially important when considering type species, as the subsequent identification of the species that compose the taxa is based on its characteristics, considered common in the group. However, despite its relevance, there are still numerous species without detailed descriptions, being especially significant among invertebrates. The family Goniodorididae is a little-known group of nudibranchs that includes eight recognized genera: Okenia, Goniodoris, Ancula, Lophodoris, Spahria, Trapania, Goniodoridella and Murphydoris. Several of their species are not completely described, including type species, and the systematics of the family is still unclear. Here we study in detail the external morphology and internal anatomy of the type species of five of the eight Goniodorididae genera using microcomputed tomography and scanning electron microscopy. We include the species Okenia elegans, Goniodoris nodosa, Ancula gibbosa, Goniodoridella savignyi and Murphydoris singaporensis as well as one species of Trapania, T. graeffei. We describe for the first time the detailed internal anatomy of the type species Goniodoridella savignyi. The diagnostic features of each genus are compared, and a preliminary framework is shown to clarify their systematics and identifications.
\end{abstract}

Keywords Micro-CT $\cdot$ Morphology $\cdot$ Taxonomy $\cdot$ Systematics $\cdot$ Type species

\section{Introduction}

In recent decades, the near absence of funding in taxonomic research, and the rapid decrease of specialists in several groups of taxa and geographic areas, has led traditional taxonomy to be an endangered science (Wheeler, 2013; Waterton, 2017). In the attempt to revitalize it, different fields for study and delimitation of species have begun to

Sofia Paz-Sedano

sofia.paz@uam.es

1 Departamento de Biología, Facultad de Ciencias, Universidad Autónoma de Madrid, Campus de Excelencia Internacional UAM + CSIC, C/ Darwin, 2, 28049 Madrid, Spain

2 Estación de Bioloxía Mariña da Graña, Universidade de Santiago de Compostela, Ferrol, Spain

3 Department of Invertebrate Zoology, California Academy of Sciences, San Francisco, CA, USA

4 Centro de Investigación en Biodiversidad Y Cambio Global (CIBC-UAM), Campus de Excelencia Internacional UAM + CSIC, Madrid, Spain integrate taxonomic studies (Tauzt et al., 2003; Hołyński, 2008; Pires et al., 2010; Wheeler, 2013; Waterton, 2017). Integrative taxonomy evaluates several lines of evidence as morphology, ecology, phylogeny, biogeography and developmental data, among others (Waterlon et al. 2013; SchlickSteiner et al., 2014; Pante et al., 2015). However, the incorporation of molecular analyses for the study of species has opened an increasingly marked shift between molecular and morphological research (Hallas \& Gosliner, 2015; Sigwart \& Lindberg, 2015; Ziegler et al., 2018), to the point that DNA sequence data are more accessible than traditional taxonomic expertise based on morphology for some taxa (Pires et al., 2010; Fedosov et al., 2019). Molecular techniques have improved their efficiency by allowing sequencing thousands of genes (Abdelkrim et al., 2018; Lemer et al., 2019) or obtaining large numbers of sequences from one target sample (deWaard et al., 2019). Nevertheless, in a less conspicuous way, the different tools for morphological analyses have also been improved and provide valuable new data for these integrative studies.

Traditionally, studies on species morphology have been done mainly through observations of external morphology 
and internal anatomy, dissections, histology or scanning electron microscopy observations. In addition, nowadays the development of digital reconstruction imaging techniques, as microcomputed tomography $(\mu \mathrm{CT})$, allows the acquisition of $2 \mathrm{D}$ and $3 \mathrm{D}$ images by non-invasive visualization even for specimens with few millimetres' length (Hoffmann et al., 2014; Xavier et al., 2015; Ziegler et al., 2018; Marcondes Machado et al., 2019). Microcomputed tomography relies on differences in X-ray attenuation of biological tissues, generates sections in three planes and reconstructs the relative position of internal and external structures of the specimen (Ziegler et al., 2018). This approach of morphological analysis using digital techniques has been termed as morphomics (Chughtai et al., 2016; Ziegler et al., 2018). The use of microcomputed tomography has several advantages against classic dissections of specimens: (1) It allows to keep the integrity of specimens under study; (2) it could facilitate the systematic re-examination of rare and valuable specimens since natural history museums would allow to study exclusive type material of poorly described but delicate specimens; (3) it allows a comprehensive analysis of external and internal features in their natural context, ensuring that structures were not affected by the invasiveness of the traditionally conducted dissections (Candás et al., 2016; Moles et al., 2017; Penney et al., 2018; Ziegler et al., 2018; Marcondes Machado et al., 2019; Schillo et al., 2019; PazSedano et al., 2021).

Within the phylum Mollusca, nudibranchs are considered a model group of study in different fields of biodiversity research due to their variability, specialization and diversification regarding their ecology, defensive strategies, natural history and biology (Goddard et al., 2011; Goodheart \& Wägele, 2020; Hallas \& Gosliner, 2015). In the last decades, the number of nudibranch species known to science has increased exponentially (Padula et al., 2014; Ekimova et al., 2016; Korshunova et al., 2017; Carmona \& Wilson, 2018). However, despite the efforts of different researchers, the taxonomy, species richness, ecology, phylogeny and biogeography of many nudibranchs are still far from known. The family Goniodorididae H. Adams \& A. Adams, 1854 is a group of very poorly known dorid nudibranchs (Gosliner, 2004). It currently includes eight genera: Okenia Menke, 1830; Goniodoris Forbes \& Goodsir, 1839; Ancula Lovén, 1846; Lophodoris G. O. Sars, 1878; Spahria Risbec, 1928; Trapania Pruvot-Fol, 1931; Goniodoridella Pruvot-Fol, 1933; and Murphydoris Sigurdson, 1991 (MolluscaBase, 2021).

The family has come to include up to 26 different genera (MolluscaBase, 2021), several of them now synonymized due to considering that some taxonomic characteristics were not supported differences (Marcus Er, 1972; Bouchet \& Ortea, 1983; Baba, 1990; Gosliner, 2004). However, few studies have been published with the attempt to clarify the systematics of the family and determine the taxonomic characteristics of each genus. Gosliner (2004) carried out the first phylogenetic analysis of the family based on morphological data. It resulted in the synonymy of the genera Hopkinsia, Hopkinsiella and Sakishimaia with Okenia (Gosliner, 2004). In addition, a phylogenetic study on the genus Trapania, also based on morphological data, explored the relationships of this genus with Okenia, Goniodoris and Ancula. However, Gosliner and Fahey (2008) were mainly focused on the evolutionary relationships and species delimitation of Trapania, whose monophyly was supported. Afterwards, phylogenetic studies on Goniodorididae started to include molecular data, but most of them are focused on Okenia species and little is known about the relationships among remaining genera (Pola et al., 2014, 2019; Paz-Sedano et al., 2017, 2021; Sales et al., 2019). In addition, three out of eight of the type species are still poorly described (Trapania fusca (Lafont, 1874), Spahria minima Risbec, 1928 and Goniodoridella savignyi Pruvot-Fol, 1933). This lack of information could lead to the placement of a species within a genus to which they do not belong. This affects not only the systematics of the family, but also biodiversity assessments, the understanding of evolutionary relationships, the development of conservation strategies and the validity of comparative studies (Neubauer et al., 2018; García-Melo et al., 2019). This problematic framework is exacerbated by the fact that the family Goniodorididae includes species of very small size (4-15 mm) and species that are cryptic or camouflaged in the environment in which they live (Gosliner, 2004; Rudman, 2004; Gosliner \& Fahey, 2008; Pola, 2015; Pola et al., 2019). These facts make it difficult to sample and collect specimens. Specifically, some species have not been found since their original description, including type species. In addition, several specimens are not accessible for the detailed studied due to their state of preservation, due to the policies of the museums themselves or even because they have been lost.

In this context, the main goal of this study is to describe in detail the anatomy of the type species of Goniodorididae either recently collected or loaned by natural history museums, to review and determine the diagnostic characteristics of each genus. Until new specimens are collected, the study and comparison of type species of the different genera of the family Goniodorididae is an initial step towards a better knowledge of the systematics of these understudied taxa. The internal anatomy of most the type species is studied under $\mu \mathrm{CT}$, showing external and internal features in their natural context, for instance, the spicule pattern and the reproductive system. Nevertheless, the scanning resolution does not allow the observation of small structures such as the radula, labial cuticle and penis of the specimens. Therefore, the descriptions are complemented by dissections and scanning electron microscope photographs. 


\section{Material and methods}

\section{Specimens}

We carried out an exhaustive search for type material and type species of each genus belonging to the family Goniodorididae deposited in natural history museums or specimens sampled by collaborators and located in their personal collections. In addition, in an attempt to collect the species considered lost by the natural museums as close as possible to the type locality, we promoted citizen science, contacting divers and naturalists from all over the world. We obtained specimens of five of eight type species. Only paratypes of Murphydoris singaporensis Sigurdson, 1991 were found, on loan from the Lee Kong Chian Natural History Museum of Singapore (Singapore). One specimen of Okenia elegans (Leuckart, 1828) from La Planassa, Girona (Spain), was loaned by the Museo Nacional de Ciencias Naturales, Madrid (Spain). Specimens of Goniodoridella savignyi Pruvot-Fol, 1993 from the Mooloolah River, Queensland (Australia), were donated by collaborators and deposited at the Australian Museum (Australia). Specimens of Goniodoris nodosa (Montagu, 1808) and Ancula gibbosa (Risso, 1818) from Norway were loaned by the Zoology Museum of Bergen University (Norway), and specimens of G. nodosa and A. gibbosa were also donated by collaborators from the White Sea (Russia) and deposited at the Museo de Ciencias Naturales (Madrid, Spain). Only one specimen identified as Trapania fusca (Lafont, 1874) from Banyuls-sur-Mer (France) was found in our attempt to examine specimens of the type species of Trapania. It was deposited at the Naturhistorisches Museum Basel (Switzerland). However, the identification of this specimen has been questioned by Doneddu et al. (2020) and is now accepted as Trapania graeffei (Bergh, 1880) (see systematic remarks of T. graeffei). We describe the detailed anatomy of this specimen since specimens of $T$. fusca are not available anywhere. Specimens belonging to Lophodoris danielsseni (Friele \& Hansen, 1876) were recently studied by some of us, and therefore, we have not included them in the present study to avoid redundancy (Paz-Sedano et al., 2021). Specimens belonging to the monotypic genus of Spahria, Spahria minima Risbec, 1928, were not available anywhere.

\section{Morphological examination}

The external morphology of the specimens was examined from photographs of living specimens and from laboratory observations. Most of the species were scanned by microcomputed tomography $(\mu \mathrm{CT})$ at "Estación de Bioloxía Mariña da Graña", University of Santiago de
Compostela (Spain), except for Okenia elegans, which had already been previously dissected by one of us (SPS). For $\mu \mathrm{CT}$ scanning, specimens were preserved in ethanol absolute; $1 \%$ iodine in $96 \%$ ethanol was used as the contrast agent, dyeing the specimens for 3 days. Afterwards, they were washed with $96 \% \mathrm{EtOH}$, dried with hexamethyldisilazane for $2-3 \mathrm{~h}$ and left to dry overnight. Imaging was performed using a microtomography Skyscan 1172, using the following parameters: source voltage $=55 \mathrm{kV}$, source current $=165 \mu \mathrm{Am}$, frames averaged $=4$ and filter $=$ no. The scanning time was 112,144 , 184, 186 and 188 min for Goniodoris nodosa, Ancula gibbosa, Trapania graeffei, Goniodoridella savignyi and Murphydoris singaporensis, respectively. Images were reconstructed with the software NRecon and cleaned with the software CTAnalyzer (http://bruker-microct.com/ products/downloads.htm). Data were corrected and visualized using DataViewer and CTVox software. Threedimensional images were visualized and edited using the Amira software for scanning successfully obtained. Raw image data and rotational movies are online available on MorphoBank (http://morphobank.org/permalink/? P3886).

Internal anatomy schematics were drawn based on $\mu \mathrm{CT}$ results. However, due to the small size of the radulae, labial cuticles and penises, these structures were not clearly observed by $\mu \mathrm{CT}$. Therefore, additional specimens of Goniodoris nodosa, Ancula gibbosa, Goniodoridella savignyi and Murphydoris singaporensis were dissected, trying to maintain their integrity as much as possible. The internal anatomy of Okenia elegans was examined under a Nikon SMZ-1500 dissecting microscope with an attached camera lucida. The buccal bulb of the specimens was submerged in $10 \% \mathrm{NaOH}$ to dissolve the surrounding tissues, and then, the radula and labial cuticle were rinsed in distilled water. The penis and labial cuticle were dried using hexamethyldisilazane, and the radula, labial cuticle and penis were examined under a Hitachi S3000N scanning electron microscope (SEM) at "Servicio Interdepartamental de Investigación", Autonomous University of Madrid, Spain. The internal anatomy of Trapania graeffei was only studied using $\mu \mathrm{CT}$ due to the availability of a single specimen.

\section{Results}

We successfully obtained reconstructed 3D images of Goniodoris nodosa, Ancula gibbosa, Trapania graeffei, Goniodoridella savignyi and Murphydoris singaporensis. Detailed descriptions of the external morphology and internal anatomy of the specimens studied are provided below, including 
photographs of the living animals, 2D tomographic images of digestive and reproductive systems, drawings of internal anatomy and scanning electron microscope photographs of the radulae, penises and labial cuticles.

Order Nudibranchia Cuvier, 1817

Family Goniodorididae H. Adams \& A. Adams, 1854

Genus Okenia Menke, 1830

Type species: Idalia elegans Leuckart, 1828, by monotypy

Okenia elegans (Leuckart, 1828)

(Figs. 1a; 2a, b; and 3a-d)

Euplocamus laciniosus Philippi, 1841: 42-59; pl. 5

Idalia cirrigera Philippi, $1844:$ iv +303 pp., pls 13-28

Idalia dautzenbergi Vayssière, 1919: 17: 53-92

Material. (MNCN 15.05/88175) Spain, Girona, Blanes, La Planassa, $20 \mathrm{~mm}$ preserved, 28/04/2016, collected by M. Ballesteros, $96 \% \mathrm{EtOH}$, dissected (SEM: radula, labial cuticle, penis).
External morphology (Fig. 1a). Preserved specimen 20-mm length. Body elongated and tall, ending in long and slightly rounded posterior end of foot. Notal border well developed, reduced, with 35 lateral papillae. Four papillae located in front of rhinophores, remaining 31 cover notal border, until posterior part of gill. Papillae elongated and slender. Two long anteriormost papillae located in front of rhinophores, up to double in length than remaining papillae. Four dorsal papillae, two in midline of body behind rhinophores and two in front of gill. Shape and size of dorsal papillae similar than posterior lateral papillae. Rhinophores none retractile, very long and slender, bearing 37 lamellae each. Rhinophoral sheath absent. Gill composed of 16 bipinnate branches, forming a closed circle around anus. Oral tentacles modified to form a flat and wide oral veil on head, ending in two rounded lobes over mouth. Foot wide and flat, protrudes from sides of body. Anterior part of foot rounded. Mantle thick and muscular, without spicules. Reproductive
Fig. 1 a Okenia elegans (Leuckart, 1828); photo: D. Poloniato, in Pola et al. (2019). b Goniodoris nodosa (Montagu, 1808); photo: I. Ekimova. c Ancula gibbosa (Risso, 1818); photo: (a) H. Jensen (ZMBM 130701), (b) I. Ekimova (MNCN 15.05/92163). d Trapania graeffei (11424 a, Basel Museum); e Goniodoridella savignyi Pruvot-Fol, 1933; photo: G. Cobb. f Murphydoris singaporensis Sigurdson, 1991 (ZRC.MOL.15663); photo: Lee Kong Chian Natural History Museum, Singapore
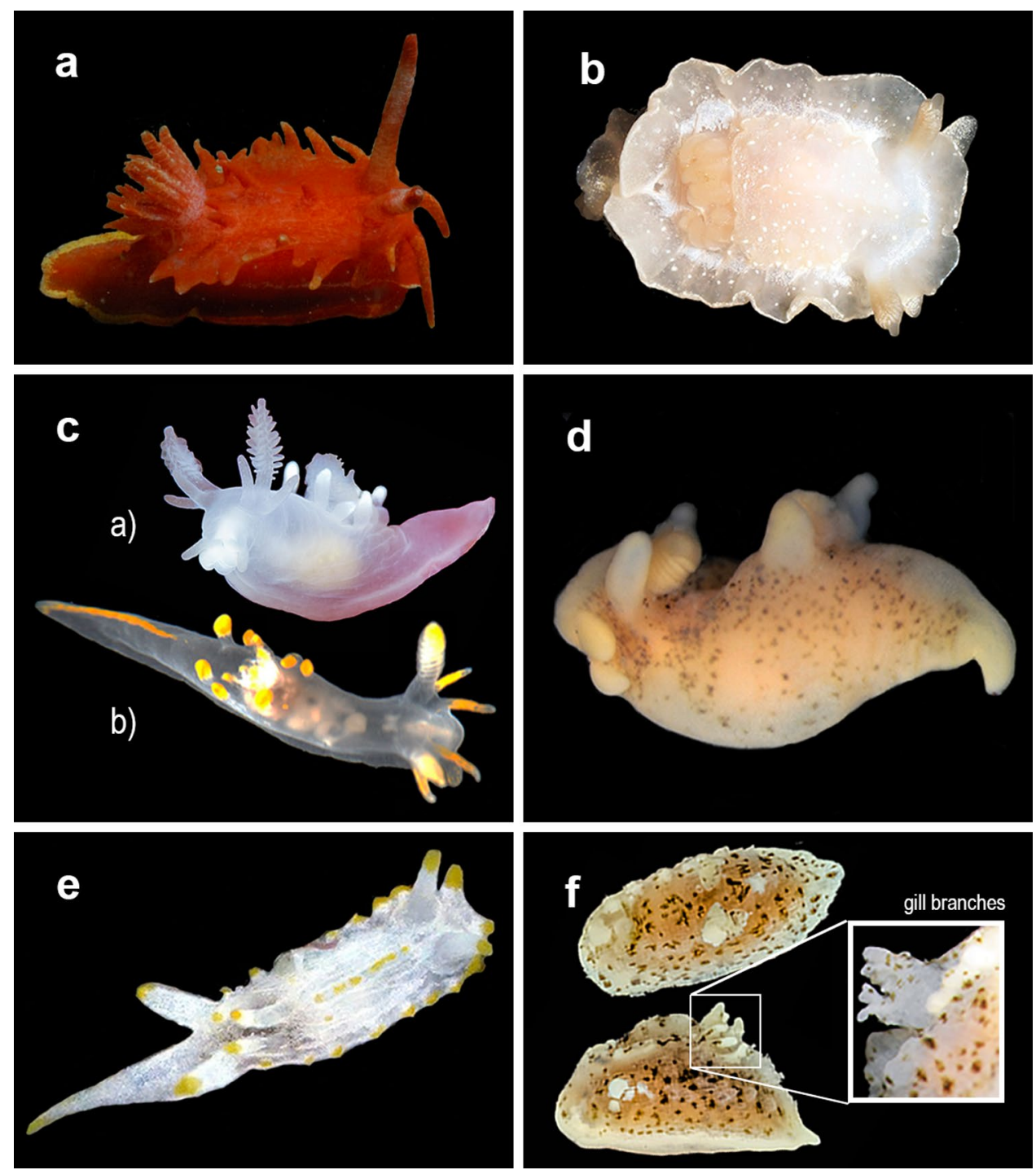


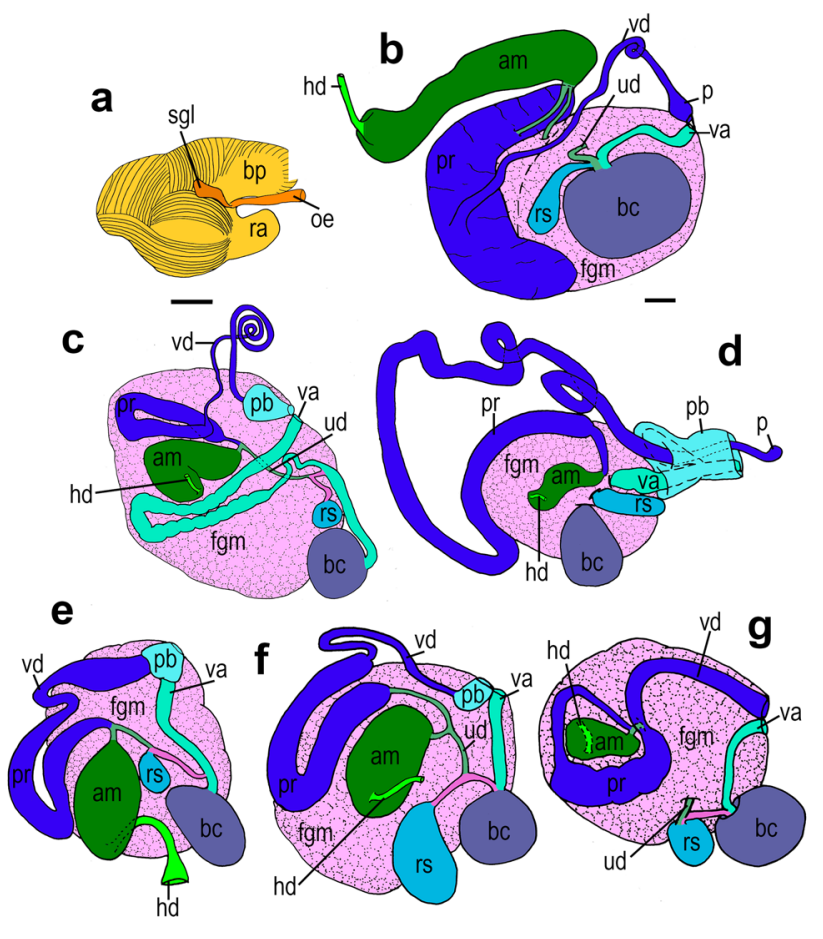

Fig. 2 Drawings of internal anatomy. a, b Okenia elegans (Leuckart, 1828) (MNCN 15.05/88175). a Buccal bulb. b Reproductive system. c Reproductive system of Goniodoris nodosa (Montagu, 1808) (MNCN 15.05/92160). d Reproductive system of Ancula gibbosa (Risso, 1818) (ZMBN 129656). e Reproductive system of Trapania graeffei (Bergh, 1880) (11,424 a). f Reproductive system of Goniodoridella savignyi Pruvot-Fol, 1933 (QMMO 85,916). g Reproductive system of Murphydoris singaporensis Sigurdson, 1991 (ZRC. MOL.15663a). am, ampulla; bc, bursa copulatrix; bp, buccal pump; fgm, female gland mass; hd, hermaphroditic duct; oe, oesophagus; $p$, penis; pb, penial bulb; ra, radular sac; rs, receptaculum seminis; sgl, salivary gland; ud, uterine duct; va, vagina; vd, vas deferens. Scale bars $1 \mathrm{~mm}$

opening located on right lateral side of body, in first third of body.

Colour pattern (Fig. 1a). Body, lateral and dorsal papillae, rhinophores and gill bright red. Lateral papillae orangish towards tips. Foot edge with orange yellowish thin band. Gill branches and rhinophores with white small patches.

Foregut anatomy (Figs. $2 \mathrm{a}$ and $3 \mathrm{a}-\mathrm{c}$ ). Buccal bulb very thick and muscular (Fig. 2a). Dorsal buccal pump large, expanding backwards (Fig. 2a). Radular sac short, located ventrally, expanding backwards (Fig. 2a). Oesophagus thin, beginning from buccal bulb behind buccal pump. Salivary glands elongated, located at junction of oesophagus with buccal bulb (Fig. 2a). Wide, oval stomach connects with digestive gland + ovotestes complex, located in its left side. Possible connections between oesophagus and stomach within digestive gland + ovotestes complex could not be studied in the already dissected specimen. Intestine thin, long, arises from stomach and continues in right side of body towards anus. Anus located dorsally on posterior part of body. Labial cuticle surrounds lips and expands within buccal pump. Surrounding lips, labial cuticle bears an armature formed by thick spikey rodlets (Fig. 3a). Radular formula $34 \times 1.1 .0 .1 .1$. Inner lateral tooth with single large and thin cusp, and wide, quadrangular base (Fig. 3b, c). Cusp large and pointed, with smooth masticatory margin (Fig. 3c). Outer corner of base ends in sort of prominent wing with pointed edge (Fig. 3c). Outer lateral tooth much smaller, slightly curved inwardly externally, resulting in large base and two pointed cusps. Upper one thinner and more pointed than lower one (Fig. 3c).

Reproductive system (Figs. $2 \mathrm{~b}$ and $3 \mathrm{~d}$ ). Reproductive system large, located in anterior third of body. Thin preampullary hermaphroditic duct begins in ovotestis, located within digestive gland + ovotestes complex. Hermaphroditic duct expands into large, thick, elongated ampulla. Two large, thin ducts emerge from ampulla. Long, narrow oviduct duct connects ampulla with female gland mass. Second duct connects ampulla to first portion of prostate. Prostate very large, elongated and sausage-shaped. From middle part of prostate, long and thin vas deferens continues, which curls slightly and expands in its final part to form ejaculatory duct. Penis with short, wide penial spines (Fig. 3d). Spines became larger and more pointed towards distal part, arranged in aligned longitudinal rows (Fig. 3d). Vagina short but similar in width to ejaculatory end of vas deferens. Vagina connects with large, rounded bursa copulatrix. At base of bursa copulatrix joins a pyriform receptaculum seminis and a thin uterine duct that enters female gland mass. Receptaculum seminis smaller than bursa copulatrix.

Remarks The genus Okenia was described by Menke in 1830. The type species is Okenia elegans, originally described from Sète, France (Mediterranean coast) (Leuckart, 1828). However, this species has not been recorded from its type locality since its original description (Pola et al., 2019). Here we study the only specimen found of Okenia elegans. It was collected in Blanes (Girona, NE Spain). This specimen was dissected in a previous study, making it impossible to study under $\mu \mathrm{CT}$ (Pola et al., 2019).

Our specimen from Girona shares the same external morphology and internal anatomy as previous descriptions of Okenia elegans (Leuckart, 1828; Vayssière, 1901, 1913, 1919). Leuckart (1828) very briefly described the species Idalia elegans, having a red body with six dorsal papillae. Afterwards, specimens collected in Banyuls-sur-Mer (France), nearby the type locality, were fully described including external and internal details and drawings (Vayssière, 1901, 1913, 1919). The features described and figured by Vayssière fit perfectly with the specimen here studied (see Vayssière, 1901, 1913, 1919).

Based on the morphological analysis of Okenia elegans and the review of the literature focused on Okenia species (Alder \& 
Fig. 3 Scanning electron micrographs of a-d Okenia elegans (Leuckart, 1828) (MNCN 15.05/88175) and e-h Goniodoris nodosa (Montagu, 1808). a Detail of jaw elements. b Frontal view of rachis and internal and external teeth. $\mathbf{c}$ Detail of internal and external teeth. $\mathbf{d}$ Penial spines. e Detail of cuticle elements (ZMBN 130629). f Frontal view of rachis and internal and external teeth (ZMBN 130629). $\mathbf{g}$ Detail of internal teeth (ZMBN 130629). h Penial spines (MNCN 15.05/92161). Scale bars: a $100 \mu \mathrm{m}$. b $300 \mu \mathrm{m}$. c $100 \mu \mathrm{m}$. d $200 \mu \mathrm{m}$. e $30 \mu \mathrm{m}$. f $300 \mu \mathrm{m}$. g $100 \mu \mathrm{m}$. h $50 \mu \mathrm{m}$
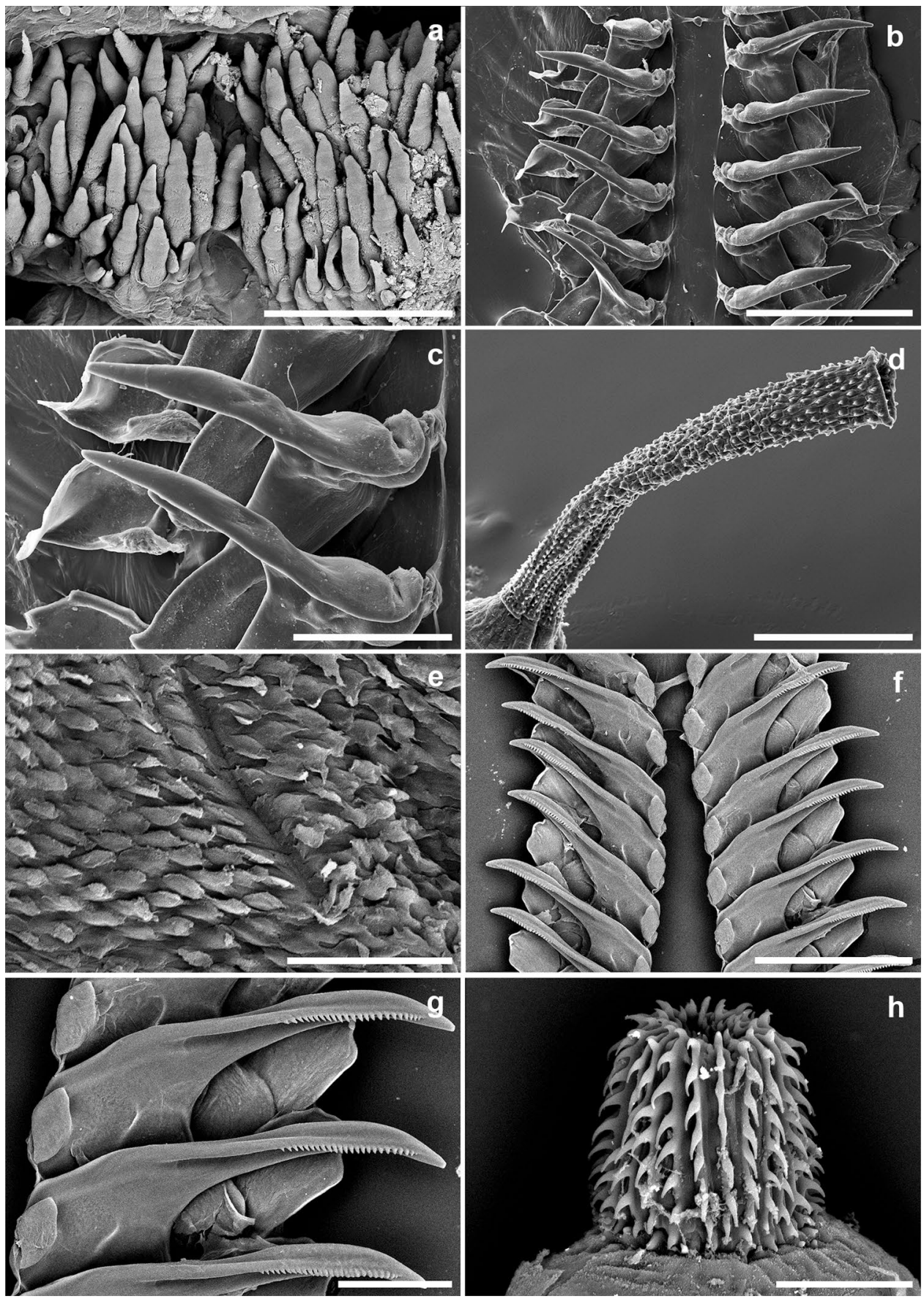

Hancock, 1845; Cervera et al., 1991; Gosliner, 2004; Gosliner $\&$ Bertsch, 2004; Rudman, 2004, 2007; Edmunds, 2009; Ortea et al., 2014; Sales et al., 2019; Pola et al., 2019), we conclude that the genus Okenia is mainly characterized by having a reduced mantle margin with lateral papillae; dorsal papillae may also be present. The rhinophores are lamellated, and surrounding the anus are a variable number of gill branches. The radula always has two different lateral teeth (Table 1). However, the genus Okenia currently includes species with wide morphological variability between species, and thus, the review of the species belonging to this genus is critical to understand the taxonomy and systematics of the genus, the family Goniodorididae and even the superfamily Onchidoridoidea Gray, 1827 (Martynov \& Schröld, 2011; Hallas \& Gosliner, 2015). As examples of this variety, the distribution along the body, the size and the shape of the papillae are very different. They can be found only on the notal edge or covering the entire body, as in Okenia academica Camacho-García \& Gosliner, 2004, Okenia hiroi (Baba, 1938); Okenia aspersa (Alder \& Hancock, 1845); or Okenia rosacea (MacFarland, 1905). Regarding the foregut anatomy, the shape 


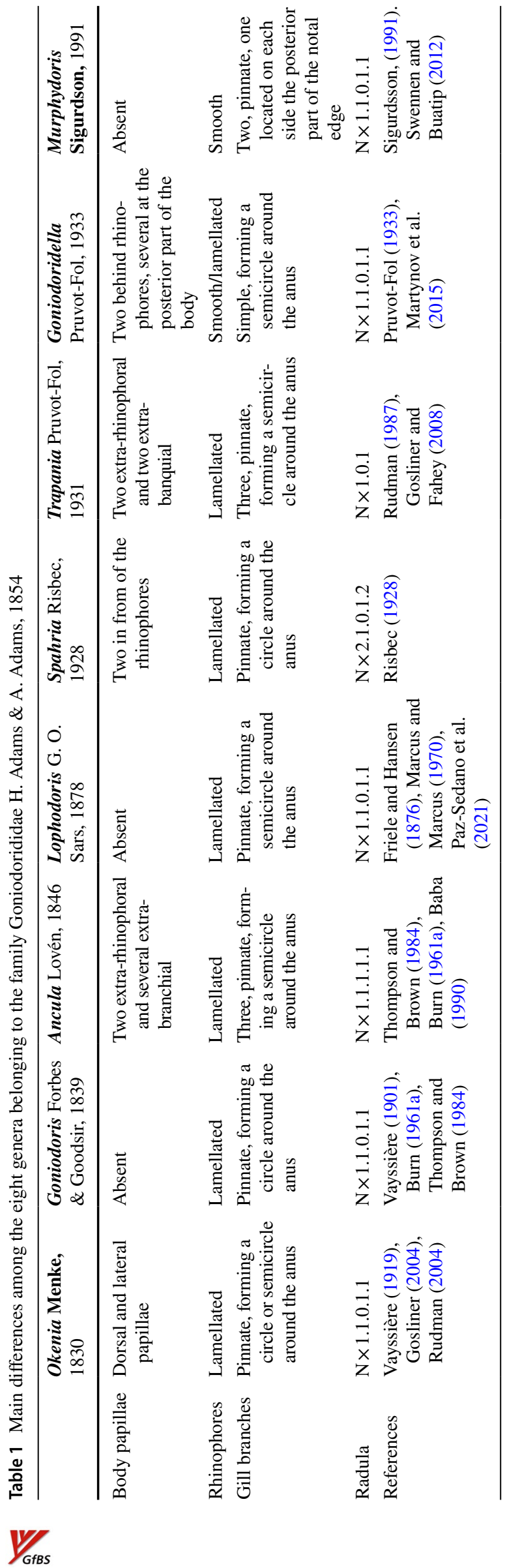

of the inner tooth may change from having a long rod-like blade without denticles (e.g. Okenia stellata Rudman, 2004) to pointed cusps with a smooth (Okenia elegans) or serrated (e.g. Okenia japonica Baba, 1949) masticatory margin. The outer lateral tooth may be small and quadrangular (e.g. Okenia barnardi Baba, 1937), small with one or two pointed cusps (e.g. Okenia mija Burn, 1967, Okenia virginiae Gosliner, 2004) or almost as long as the inner tooth with one or two cusps (e.g. Okenia vena Rudman, 2004 and Okenia rhinorma Rudman, 2007). In the reproductive system, there are also some remarkable differences, such as the position and size of the receptaculum seminis, which could become a very small structure near the bursa copulatrix (e.g. Okenia pilosa (Bouchet \& Ortea, 1983), Okenia plana Baba, 1960). Another taxonomic characteristic with differences among Okenia species is the presence/absence of spicules in the mantle. The type species Okenia elegans has a muscular mantle lacking spicules, while species as Okenia aspersa Alder \& Hancock, 1845; Okenia mediterranea (Ihering, 1886); Okenia picoensis Paz-Sedano et al., 2017; Okenia rosacea (MacFarland, 1905); or Okenia zoobotryon (Smallwood, 1910) have spicules embedded in the mantle, covering the body or within the papillae (Cervera et al., 1991; Pola et al., 2014; Paz-Sedano et al., 2017; Penney et al., 2018). This wide variety may suggest that Okenia could include species that do not belong to this genus and synonymized genera could be recovered. The present study of Okenia elegans and its comparison with the remaining type species determines the basic diagnostic characters of the type species, which will help future taxonomists to assign species to a genus in a more accurate way (see discussion).

Genus Goniodoris Forbes \& Goodsir, 1839

Type species Doris nodosa Montagu, 1808, by monotypy Goniodoris nodosa (Montagu, 1808)

(Figs. 1b; 2c; 3e-h; 4a, b; and 5a-c).

Doris nodosa Montagu, 1808: v +183 pp., pls 17-30

Doris barvicensis G. Johnston, 1838: 44-56

Goniodoris emarginata Forbes, 1840: 102-108, pl. 2

Doris elongata W. Thompson, 1840: 4-102, pl. 2

Material. (MNCN 15.05/92160) Russia, Murmansk Oblast, Teriberka, 12-14-m depth, $12 \mathrm{~mm}$ preserved, 15/05/2019, collected by I. Ekimova, 96\% EtOH, $\mu \mathrm{CT}$ scanning; (MNCN 15.05/92161-MNCN 15.05/92162) Russia, Barents Sea, Teriberka Bay, collected by T. I. Antokhina, $96 \%$ EtOH, (MNCN 15.05/92161) $10 \mathrm{~m}, 18 \mathrm{~mm}$ preserved, 25/08/2018, dissected (SEM: radula, penis), (MNCN 15.05/92162) $18 \mathrm{~m}$, 30/08/2018, dissected (SEM: radula); (ZMBN 125097, ZMBN 125097.1) Norway, Gylte Brygge, Drøbak, Frogn, Akershus, collected by Drøbak team 2018, 96\% EtOH, (ZMBN 125097) $14 \mathrm{~mm}$ preserved, (ZMBN 125097.1) $10 \mathrm{~mm}$ preserved; (ZMBN 125696, ZMBN 125696.1) Norway, Egersund havn, Egersund, Eigersund, Rogaland, 12-m depth, 19/01/2019, collected by E. Svensen, 96\% EtOH, (ZMBN 125696) $15 \mathrm{~mm}$ preserved, (ZMBN 125696.1) $7 \mathrm{~mm}$ preserved; (ZMBN 130629) Norway, Hellersøy, Mandal, 


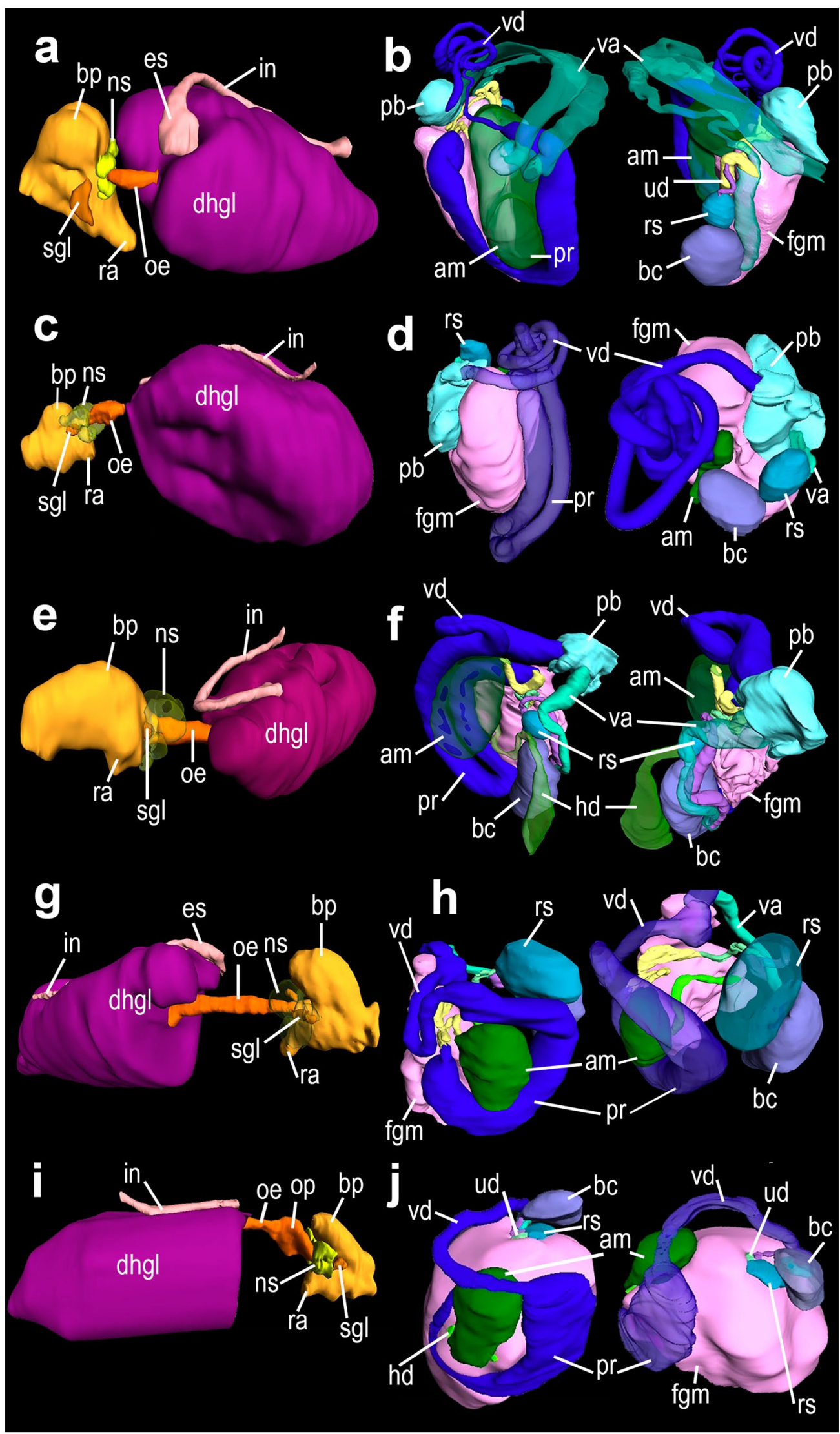


४Fig. 4 Microcomputed tomography reconstructions of internal anatomy. a, b Goniodoris nodosa (Montagu, 1808) (MNCN 15.05/92160). a Digestive system. b Reproductive system. c, d Ancula gibbosa (Risso, 1818) (ZMBN 129656). c Digestive system. d Reproductive system. e, f Trapania graeffei (Bergh, 1880) (11,424 a). e Digestive system. f Reproductive system. g, h Goniodoridella savignyi Pruvot-Fol, 1933 (QMMO 85,916). g Digestive system. h Reproductive system. i, j Murphydoris singaporensis Sigurdson, 1991 (ZRC.MOL.15663a) i Digestive system. j Reproductive system. am, ampulla; bc, bursa copulatrix; bp, buccal pump; dhgl, digestive gland + ovotestes complex; fgm, female gland mass; hd, hermaphroditic duct; in, intestine; ns, nervous system; oe, oesophagus; op, oesophagal pump; p, penis; pb, penial bulb; ra, radular sac; rs, receptaculum seminis; sgl, salivary gland; st, stomach; ud, uterine duct; va, vagina; vd, vas deferens

Vest-Agder, $10 \mathrm{~mm}$ preserved, 24/05/2019, collected by Mandal Team 2019, $96 \%$ EtOH, dissected (SEM: radula, labial cuticle).

External morphology (Fig. 1b). Preserved specimens 7-18-mm length. Body rounded, ending in long and pointed posterior end of foot. Mantle edge well developed, covering body. Body lacks dorsal and lateral papillae but several tubercles cover dorsum with no apparent pattern. Rhinophores none retractile, slender, bearing 14-17 lamellae each. Rhinophoral sheaths absent. Gill composed of 11-14 tripinnate branches forming a circle around anus. Oral tentacles broad and flattened, triangle-shaped, extend in front of head. Foot wide and flat, covered by mantle with exception of most posterior part, where extension of foot gives rise to tail. Reproductive opening located on right lateral side of the body, in first third of body.

Colour pattern (Fig. 1b). Body translucent white, with disperse hyaline white dots along dorsum, side of body and oral tentacles. Rhinophores and gill branches pinkish with white traces in lamellae and pinnae.

Foregut anatomy (Figs. 3e-g and 4a). Buccal bulbs of specimens from White Sea (Russia) were previously removed and studied by Ekimova et al. (2019). We review here its features in a specimen from Norway (ZMBN 130629). Buccal bulb very thick and muscular (Fig. 4a). Dorsal buccal pump rounded, expanding backwards. Radular sac large, ventral, expanding backwards (Fig. 4a). Oesophagus thin, beginning from buccal bulb, behind buccal pump. Elongated salivary gland located at junction of oesophagus with buccal bulb (Fig. 4a). Nervous system covers this union. Oesophagus continues and inserts into digestive gland + ovotestes complex. Stomach and oesophagus concur in diffuse chamber inside digestive gland + ovotestes complex. Small, oval stomach located in left side of body. Thin and long intestine begins in stomach, run towards right side of body and ends in anus. Anus located dorsally, at posterior part of body (Fig. 4a). Labial cuticle surrounds lips and expands inside buccal pump. Labial cuticle covered by thin and flat, scale-shaped elements (Fig. 3e). Radular formula
18-21 × 1.1.0.1.1. Inner lateral tooth with single large cusp and wide wing-shaped base (Fig. 3f, g). Cusp pointed, with masticatory margin bearing 16-25 small and sharp denticles. Base of inner lateral tooth rectangular, with rounded and curved inwards edge (Fig. 3f, g). Outer lateral tooth much smaller, smooth, and rectangular (Fig. 3g).

Reproductive system (Figs. 2c, 3h and 4b). Reproductive system large, located in anterior third of body. Thin preampullary hermaphroditic duct begins in ovotestis, located within digestive gland + ovotestes complex. Hermaphroditic duct expands in large, kidney-shaped ampulla. Short, narrow postampullary duct divides into oviduct and prostatic portion of vas deferens. Prostate thick and relatively large, descends and turns ampulla. Prostate becomes very thin, long vas deferens, very coiled for much of its length. Distal part of vas deferens enters in large pear-shaped penial bulb. Penis armed, located inside penial bulb. Penial spines thin, sharp, very pointed, arranged in rows (Fig. 3h). Vagina very long, almost as wide as prostate. Vagina characterized by having flat shape close to genital opening. It becomes a round tube with thinner screwed tube inside. Externally, it seen as an irregular widening. After seemingly irregular area, vagina becomes very narrow and widens again on its way to bursa copulatrix. Bursa copulatrix large and slightly oval. Following narrowing of vagina, thin duct arises and divides into short duct that connects to receptaculum seminis and uterine duct. Receptaculum seminis small and rounded, almost half size of bursa copulatrix. Long uterine duct continues to connection with ampulla.

Spicule pattern (Fig. 5a-c). Body supported by dense network of spicules, which includes mantle, foot, gill branches, oral tentacles and rhinophores. More concentrated and numerous ventrally. Spicules elongated, wider at middle part and sharp at apices. Tubercles of mantle, gill branches and crest of mantle supported by disorganized set of spicules at base, with several spicules from mantle, joining at dorsal part as pyramid-shaped. Spicules at mantle edge support serrated margin, pointed outwards (Fig. 5a, b). Rhinophores with dense amount of curved and small spicules, forming a tube supporting entire structure (Fig. 5b). On foot, spicules forming intercalated meshwork. Spicules of foot wider and longer, arranged transversally from sides to centre (Fig. 5c).

Remarks The genus Goniodoris was first proposed by Forbes and Goodsir (1839) as a new genus based on specimens of Doris nodosa Montagu, 1808, making Goniodoris nodosa the type species of the genus. Goniodoris nodosa was first described from Great Britain. Its current distribution ranges from the Mediterranean Sea to Russian waters (Nobre, 1932; Bouchet \& Tardy, 1976; Urgorri \& Besteiro, 1983; Thompson \& Brown, 1984; García-Gómez et al., 1991; Cervera et al., 2004; Evertsen \& Bakken, 2005; NayaGarmendia, 2016; Ekimova et al., 2019). The species is well distinguished by its white coloration and body shape, with a 
Fig. 5 Spicule patterns using microcomputed tomography. a Lateral view of Goniodoris nodosa (Montagu, 1808) (MNCN 15.05/92160). b Detail of anterior dorsal spicules of $G$. nodosa (MNCN 15.05/92160). c Ventral view of $G$. nodosa (MNCN 15.05/92160). d Lateral view of Goniodoridella savignyi Pruvot-Fol, 1933 (QMMO 85,916). e Dorsal view of $G$. savignyi (QMMO 85,916). f Ventral view of $G$. savignyi (QMMO 85,916). Scale bars: a-c $250 \mu \mathrm{m}$. d-f $100 \mu \mathrm{m}$
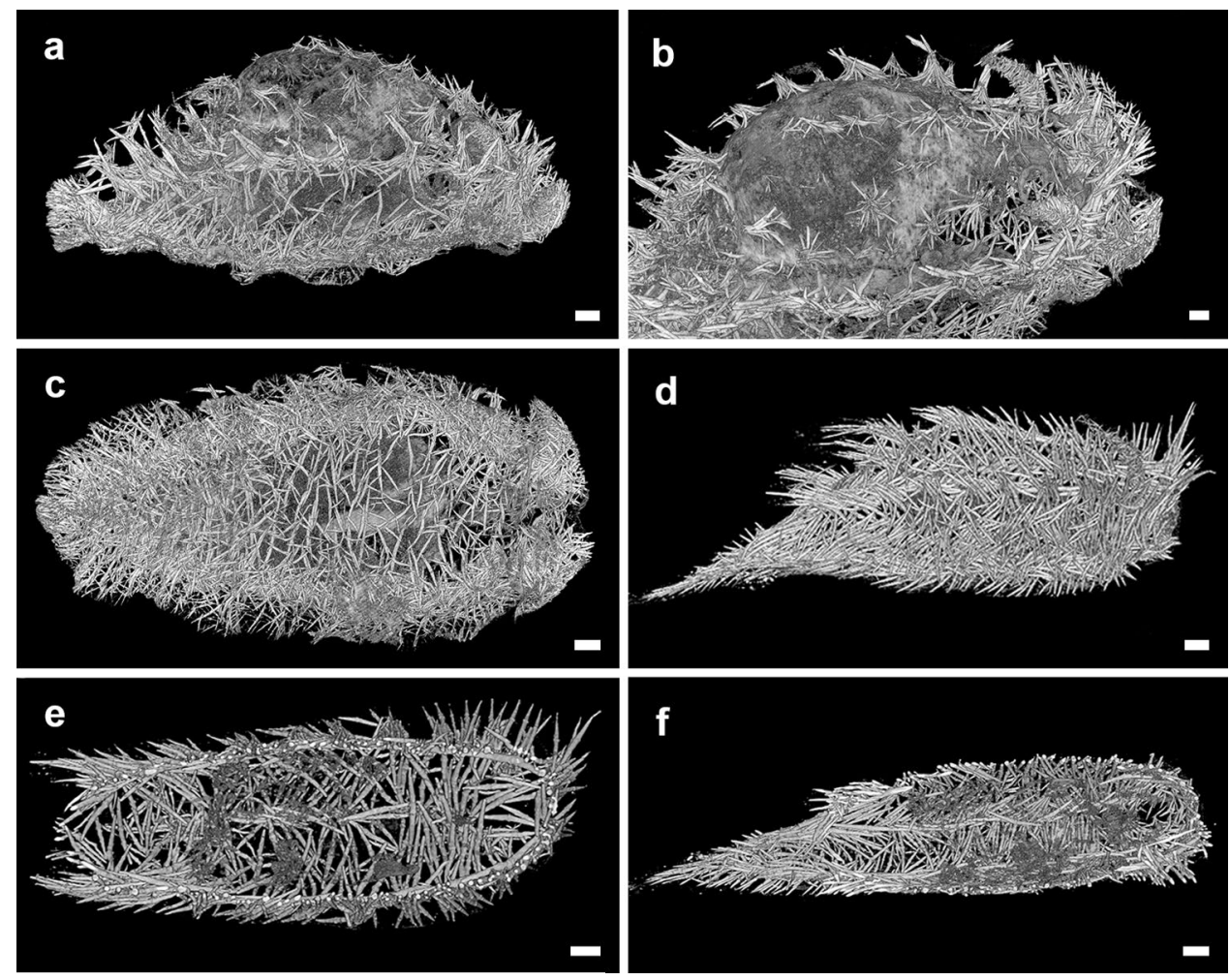

well-developed mantle margin and a pair of expanding oral tentacles in front of the head. The external morphology of the species has been described by several authors based on specimens collected in different countries of north Europe (Alder \& Hancock, 1845; Thompson \& Brown, 1984; among others), as well as radula details (Miller, 1958; Thompson \& Brown, 1984; Ekimova et al., 2019). The external morphology and the radula of the specimen here studied match with previous descriptions. Internally, only few details of the reproductive system were previously described by Lloyd (1952) and more recently by Ekimova et al. (2019). Lloyd (1952) compared the reproductive system of G. nodosa in a discussion focused on its differences with the species Archidoris britannica (Johnston, 1838) (originally described as Doris britannica Johnston, 1838; currently accepted as Doris pseudoargus Rapp, 1827), describing it as "the vaginal duct is longer and thrown into a V-shaped bend above the buccal mass; the bursa copulatrix is extremely large and may be divided into a spherical proximal half, containing sperm and prostatic fluid and a club shaped distal half which has brownish purple contents". Afterwards, Ekimova et al. (2019) provided more details of the reproductive system, describing a sausage-shaped ampulla and receptaculum seminis, a small oval bursa copulatrix, a long vas deferens with a prominent prostate and a muscular penial bulb with a short penis. Both descriptions included information of the bursa copulatrix; however, the size and shape vary. We studied the internal anatomy of the specimens analyzed by Ekimova et al. (2019).
However, the morphology of the bursa copulatrix agrees with the description of Lloyd (1952), being likely that Ekimova et al. (2019) confused the bursa copulatrix and the receptaculum seminis. We consider that the bursa copulatrix of the specimen here studied under $\mu \mathrm{CT}$ is defined more accurately having a slightly oval shape than a sausage shape. Maybe this interpretation could be influenced by the position and manipulation of the reproductive system during dissection in previous studies. Also, it may vary based on the reproductive state of individual specimens.

Based on the morphological analysis and the review of previous descriptions of species belonging to the genus Goniodoris, we can conclude that the genus differs from other Goniodorididae genera by having a smooth mantle brim which covers the body and an oral veil flattened, forming tentaculiform lobes. The body lacks dorsal and lateral papillae, but present small tubercles supported by spicules on the dorsum, sides of the body and behind the mantle brim. The rhinophores are lamellated, and there are a variable number of tripinnate gill branches, forming a circle surrounding the anus. The radula has one inner and one outer lateral tooth (Table 1) (Abraham, 1877; Vayssière, 1901; Burn, 1961a, b; Thompson \& Brown, 1984, among others).

Genus Ancula Lovén, 1846

Type species: Polycera cristata Alder, 1841, by monotypy

Ancula gibbosa (Risso, 1818)

(Figs. 1c; 2d; 4c, d; and 6a-f)

Tritonia gibbosa Risso, 1818: 368-377 
Polycera cristata Alder, 1841: 337-342; pl. 9

Ancula cristata Alder, 1841: 337-342; pl. 9

Ancula sulphurea Stimpson, 1853: 1-66; pls 1-3

Ancula pacifica McFarland, 1905: 35-54

Material. (ZMBN 130701) Norway, Gåsvær, Sogn og Fjordane, 30-m depth, $4 \mathrm{~mm}$ preserved, 01/06/2019, collected by H. Jensen, 96\% EtOH, dissected (SEM: radula, labial cuticle, penis); (ZMBN 129782) Norway, Oslofjorden, Drøbak, Akershus, 17-m depth, $7 \mathrm{~mm}$ preserved, 16/03/2019, collected by H. Jensen; (ZMBN 129656)
Norway, Espegrend, Hordaland, 4-m depth, $5 \mathrm{~mm}$ preserved, 29/03/2019, collected by Espegrend workshop 2019, $\mu$ CT scanning; (MNCN 15.05/92163, MNCN 15.05/93237-15.05/93237) Russia, N.A. Pertzov White Sea Biological Station, collected by I. Ekimova (MNCN 15.05/92163) 10-m depth, $5 \mathrm{~mm}$ preserved, 05/07/2016, (MNCN 15.05/93237) 10-m depth, $5 \mathrm{~mm}$ preserved, 28/06/2016, dissected (SEM: radula, labial cuticle, penis), (MNCN 15.05/93238) 10-m depth, $4 \mathrm{~mm}$ preserved, 28/06/2016, dissected (SEM: radula, labial cuticle, penis),
Fig. 6 a-f Scanning electron micrographs of Ancula gibbosa (Risso, 1818) and $\mathbf{g}$ photographs of labial cuticle and radula under microcomputed tomography of Trapania graeffei (Bergh, 1880) (11424a, Basel museum). a Jaw elements (MNCN 15.05/93237). b Detail of jaw elements (MNCN 15.05/93238). c Detail of honeycomb-shaped elements. d Frontal view of rachis and internal and external teeth (ZMBN 130,701). e

Detail of half radula (ZMBN 130701). f Penial spines and cilia (MNCN 15.05/93238). Scale bars: a $100 \mu \mathrm{m}$. b $10 \mu \mathrm{m}$. c $10 \mu \mathrm{m}$. d $50 \mu \mathrm{m}$. e $30 \mu \mathrm{m}$. f $100 \mu \mathrm{m}$
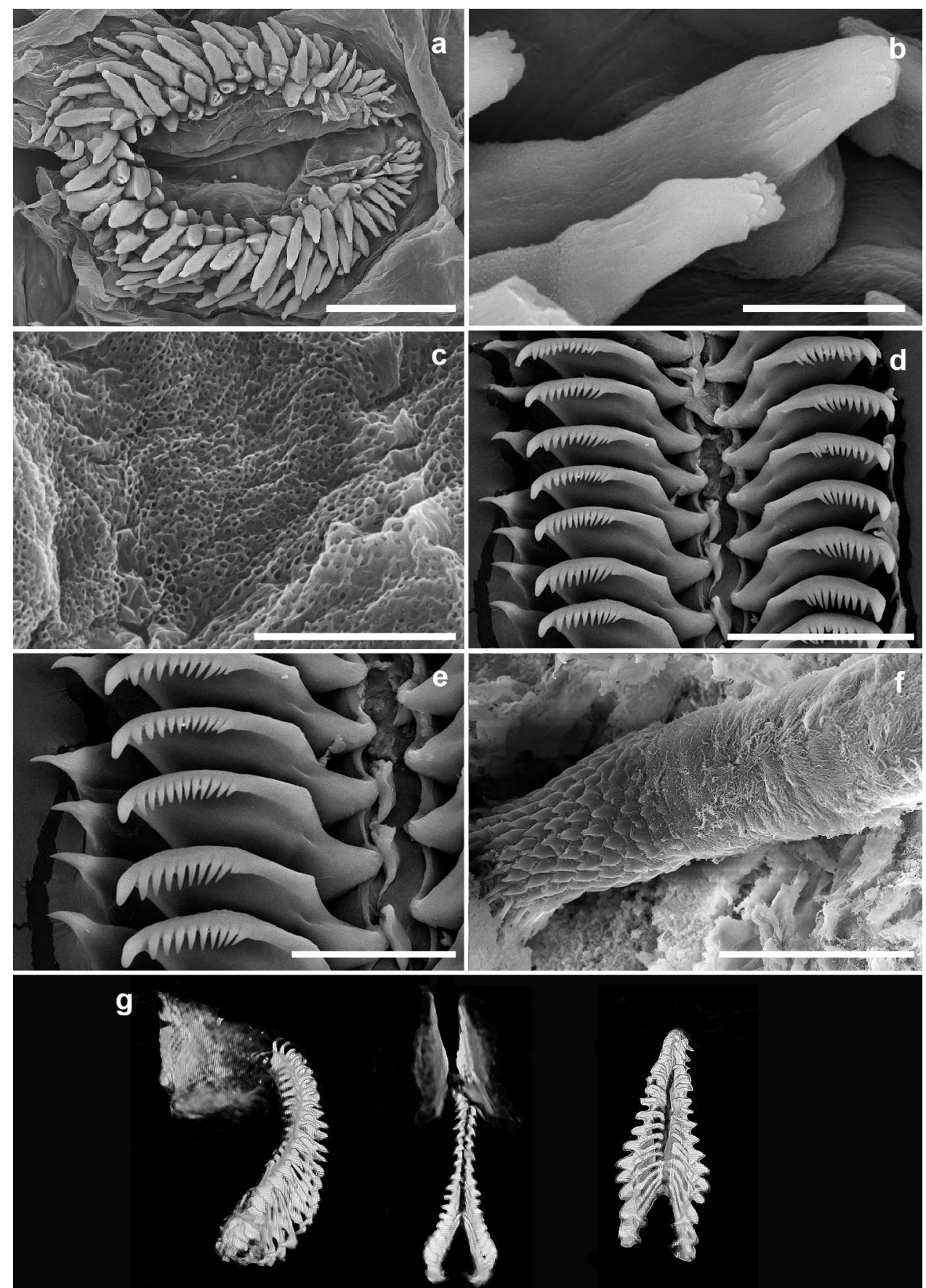
(MNCN 15.05/93239) 10-15-m depth, 4 mm preserved, 29/06/2016, dissected (SEM: radula, labial cuticle, penis).

External morphology (Fig. 1c). Preserved specimen 4-7$\mathrm{mm}$ length. Body elongated and slender, ending in long and pointed posterior end of foot. Developed notal border absent. Two thin and slender papillae located at base of each rhinophore. Ten to twelve dorsal papillae surround gill, 5-6 on each side. Dorsal papillae shorter and thicker than anterior ones, with rounded and more swollen tip. Rhinophores none retractile, bearing 9-12 lamellae each. Rhinophoral sheaths absent. Gill composed of 3 tripinnate branches, forming a semicircle around anus, opened at posterior part. Oral tentacles digitiform, one on each side of mouth. Mantle thick, lacks spicules. Reproductive opening located on right lateral side, in first third of body.

Colour pattern (Fig. 1c). We studied two morphotypes of Ancula gibbosa: (a) with body, anterior papillae, rhinophores and gill branches translucent whitish. Papillae surrounding gill branches transparent whitish at base with hyaline white from middle to tip; (b) entire body translucent whitish. Base of papillae, gill branches and rhinophores translucent whitish as body colour. Anterior papillae orangish yellow in middle part, with translucent tips. Rhinophores with white colour at middle part and yellow tips. Gill branches and papillae surrounding gill with orangish yellow from middle to tip. Posterior part of body, behind gill, with middorsal orange line, approximately from third posterior part of body to end.

Foregut anatomy (Figs. 4c and 6a-e). Buccal bulb thick and muscular (Fig. 4c). Dorsal buccal pump rounded, expanding backwards. Radular sac short, located at posterior part of buccal bulb (Fig. 4c). Oesophagus thin, beginning from buccal bulb, between buccal pump and radular sac. Small, oval salivary glands located at junction of oesophagus with buccal bulb. Nervous system covers this junction. Dense number of oral glands surrounding mouth. Oesophagus continues and inserts into digestive gland + ovotestes complex. Stomach and oesophagus concur in diffuse chamber inside digestive gland + ovotestes complex. Small, kidney-shaped stomach located in dorsal left part of body. Thin and long intestine begins in stomach, run slightly towards right side and ends in dorsal, posterior anus (Fig. 4c). Labial cuticle surrounds lips and expands inside buccal pump. Surrounding lips, labial cuticle armed. Elements smooth, cylindrical, ending in a cusp with rounded tubercles (Fig. 6a, b). Inside the buccal pump, labial cuticle with honey-shaped elements (Fig. 6c). Radular formula 25-27× 1.1.1.1.1. Rachidian tooth small and rectangular. Inner lateral tooth rectangular with wide base (Fig. 6d, e). Upper part folded inwards giving place to masticatory margin. Masticatory margin with one large, wide denticle, followed by 10-12 smaller denticles which become thinner and smaller towards inner part (Fig. 6d, e). Outer lateral tooth much smaller, conical, with single sharp cusp (Fig. 6e).
Reproductive system (Figs. 2d, 4d and 6f). Reproductive system located in anterior third of body. Thin hermaphroditic duct begins in ovotestis, located within digestive gland + ovotestes complex. Preampullary hermaphroditic duct expands in small sausage-shaped ampulla. Ampulla continues into short, narrow postampullary duct, which bifurcates into long, wide prostate and narrow oviduct. Width of prostate and vas deferens without morphological differentiation. Vas deferens long and coiled, ending in penis at most distal part. Penis with numerous cilia along the penis and hooked penial spines only located at base (Fig. 6f). Vagina similar in width to vas deferens. Penis and vagina partially inside large muscular penial bulb. Vagina short and enters in female gland mass by very short and thin duct. Bursa copulatrix large and oval; receptaculum seminis elongated. Both appear to connect independently and directly to female gland mass through very short duct. Receptaculum seminis slightly smaller than bursa copulatrix.

Remarks The genus Ancula Lovén, 1846 was originally proposed based on change of identification of Polycera cristata Alder, 1841 type material. Later, Pruvot-Fol (1954) declared the species Tritonia gibbosa Risso, 1818 as Ancula and synonym of Ancula cristata. While Polycera cristata remains as the type species of Ancula, it is considered a junior synonym of Ancula gibbosa. The genera Drepaniella and Eucrairia are also synonyms of Ancula. The genus Drepaniella Burn, 1961 (type species Drepaniella mapae Burn, 1961) was described as a new genus mainly due to the difference of having one bifurcated process at the base of each rhinophore, instead of a pair of single rhinophoral process as occurs in Ancula (Burn, 1961a). However, this name was already preoccupied by a genus of Hemiptera, so it was replaced for Eucrairia Burn, 1961 (Burn, 1961b). Subsequently, in 1972, Er. Marcus considered that the state of the processes was not a sustained difference. Thus, Drepaniella and Eucrairia become synonymous with Ancula. Years later, these synonyms were questioned, and Baba (1990) suggested the revision of the genus and its likely new division, proposing the use of Ancula for the species with several extra-branchial papillae on each side, and Eucrairia for the species with a single extra-branchial papilla on each side. This morphological difference was not previously mentioned by Er. Marcus (1972) or Burn (1961a). After the results here obtained and the bibliographic revision of Ancula species, two important features led us to think that the genus Eucrairia could be recovered in future studies: (1) the number of papillae surrounding the anus as proposed by Baba (1990) and (2) the presence/absent of the central tooth. The presence of a central tooth has only been observed in specimens identified as Ancula gibbosa, which have several papillae around the anus (Thompson \& Brown, 1984; Baba, 1990). The remaining species, Ancula espinosai Ortea, 2001; Ancula evelinae Er. Marcus, 1961; Ancula fuegiensis 
Odhner, 1926; Ancula kariyana Baba, 1990; Ancula lentiginosa Farmer \& Sloan, 1964; and Ancula mapae (Burn, 1961), are described having only one papilla on each side of the gill branches and, when information is available, they lack rachidian teeth. Here we determined that the radular formula of species of Ancula is $\mathrm{N} \times 1.1 .1 .1 .1$. However, further phylogenetic studies using type material or newly collected material of different Ancula species are needed to accept or reject the recovery of the genus Eucrairia and consider both genera Ancula and Eucrairia as monophyletic.

Although the systematic revision of species belonging to Ancula is still needed, specimens here studied share the same characteristics as the description of Ancula cristata (Alder, 1841), original type species of the genus Ancula. Ancula cristata was first sampled from Cullercoats, England. It was described as having transparent white body and may have a wide variety of orange-yellow pattern along its different body structures. Rhinophores pale yellow which may be tipped with bright orange. There are two papillae at the base of each rhinophore. Branchial gill three, with a transparent white colour and may have yellow tips. Gill surrounded by ten papillae which may have orange or pale-yellow tips. Posterior end of foot may be marked with an orange central line. The species lacks spiculae (Alder, 1841; Alder \& Hancock, 1845; Baba, 1990). The digestive and reproductive systems of $A$. gibbosa were previously described by Er. Marcus (1961) and Baba (1990). Despite the doubts on the systematics of the genus, based on our study of the type species Ancula Lovén, 1846 , it is distinguished by having rhinophores lamellated, a pair of papillae situated at the base of each rhinophore, a variable number of papillae beside the gill and three gill branches arranged in a semicircle around the anus. Internally, the radular formula is $\mathrm{N} \times 1.1 .1 .1 .1$, and the penis is armed (Table 1) (Alder \& Hancock, 1845; Lovén, 1846; Forbes \& Hanley, 1853; Pruvot-Fol, 1954; Burn, 1961a; Er. Marcus, 1972; McDonald, 1983; Baba, 1990).

Genus Trapania Pruvot-Fol, 1931

Type species Trapania fusca (Lafont, 1874), by monotypy

Trapania graeffei (Bergh, 1880)

(Figs. 1d; 2e; 4e, f; and 6g)

Drepania graeffei Bergh, 1880: 599-652, pls 9-14

Material. (11,424 a, Basel Museum) France, Banyulssur-Mer, $3 \mathrm{~mm}$ preserved, 02/03/1985, collected by H. R. Haefelfinger, $\mu \mathrm{CT}$ scanning.

External morphology (Fig. 1d). Preserved specimen 3-mm length. Body elongated, ending in pointed end of foot. Body lacks distinct notal border. One extra-rhinophoral appendage located on side of each rhinophore, elongated and short, orientated backwards. One extra-branchial appendage with same shape and size as extra-rhinophoral appendages on each side of gill. Rhinophores none retractile, long and elongated, bearing 7 lamellae each. Rhinophoral sheaths absent. Gill composed of three tripinnate branches, forming semicircle around anus. Oral tentacles long and elongated. Foot thin. Anterior part of foot with two long and elongated propodial tentacles. Mantle thick and muscular, lacks spicules. Reproductive opening located on right lateral side in first third of body.

Colour pattern (Fig. 1d). Body colour of living animal well described by Bergh (1881). However, specimen here studied preserved some details of body colour. Figure 1d shows a photograph taken under the light microscope of the borrowed specimen. Body of preserved specimen translucent, orangish due to internal organs. Preserved specimen retains brown spots along body. Brown spots more concentrated behind rhinophores, forming two patches from rhinophores towards extra-branchial processes, becoming more dispersed on foot.

Foregut anatomy (Figs. 6e and 6g). Buccal bulb large, thick and muscular (Fig. 4e). Elongated dorsal buccal pump, expanding posteriorly (Fig. 4e). Radular sac small, short, ventral and expanding posteriorly (Fig. 4e). Oesophagus thin, beginning from buccal bulb, behind buccal pump. Pair of very small, rounded salivary glands located at junction of oesophagus with buccal bulb (Fig. 4e). Nervous system covers this junction. Oesophagus continues posteriorly and inserts into digestive gland + ovotestes complex. Stomach and oesophagus join in diffuse chamber inside digestive gland + ovotestes complex. Small, thin stomach located in dorsal left part of body. Thin and long intestine begins in stomach, runs upwards and turns towards right side of body. Intestine terminates in dorsal, posterior anus (Fig. 4e). Studied specimen of Trapania graeffei was not dissected because, to date, only one specimen has been found in the collections of the several museums consulted. Therefore, we decided not to study the radula and the labial cuticle under the scanning electron microscope in order to maintain the integrity of the animal. However, some details of these structures could be observed thanks to $\mu \mathrm{CT}$ (Fig. $6 \mathrm{~g}$ ). Labial cuticle armed and surrounds lips (Fig. 6g). Radular formula approximately $21 \times 1.0 .1$. Lateral teeth with one large outer cusp and variable number of pointed denticles along masticatory margin (Fig. 6g). No further details can be determined due to resolution of the scanning.

Reproductive system (Figs. 2e and 4f). Reproductive system located in anterior third of body. A wide preampullary hermaphroditic duct originates in ovotestis, located within digestive gland + ovotestes complex. Hermaphroditic duct expands in very large and oval ampulla. Postampullary duct short and narrow, divides into oviduct and prostatic portion of vas deferens. Thick, large and bent prostate becomes relatively short and narrows into thinner vas deferens. Distal part of vas deferens enters penial bulb, covering penis and vagina. Penial spines could not be observed under microcomputed tomography. Vagina relatively long, slightly wider close to genital opening. Vagina connects with large and

$$
V_{G \in B S}
$$


ovoid bursa copulatrix. Long, narrow duct connects with elongated and small receptaculum seminis at base of bursa copulatrix. Short and thin uterine duct arises at base of receptaculum and enters the female gland mass.

Remarks The type species of the genus Trapania, Trapania fusca (Lafont, 1874), was first described from Arcachon (France) as Drepania fusca. However, this name was already pre-occupied by a group of Hemiptera, and thus, Pruvot-Fol (1931) proposed its change to Trapania (Kress, 1968). In spite of being the type species of the genus, its synonym with two other species, Trapania graeffei (Bergh, 1880) and Trapania tartanella (Ihering, 1886), has been accepted for years (Doneddu et al., 2020). Trapania graeffei (Bergh, 1880) was originally described from Tegueste (Adriatic Sea), without any comparison with T. fusca. Trapania tartanella was described from Napoli (Italy), as a new species with differences in the number of penial spines and lack of black dots on the back, which are present in T. graeffei and T. fusca (Ihering, 1886). However, in describing T. tartanella, Ihering (1886) left some doubts about its differences with T. fusca, specifying that further anatomical studies would be necessary comparing both species. At that moment, these three species were not completely described, lacking details of the internal anatomy of all of them, and morphological differences started to be questioned by several authors. Pruvot-Fol (1954) and Schmekel (1968) considered T. tartanella and T. graeffei juveniles of T. fusca, while Baba (1935) and MacFarland (1966) maintained T. tartanella and T. graeffei as synonyms, keeping T. fusca as different species. Ortea et al. (1989) and Cervera et al. (2000) support T. tartanella, T. graeffei and $T$. fusca as three independent species.

To date, most authors have accepted that $T$. tartanella is a different species from T. graeffei and T. fusca, based on the colour pattern and radula features, but there were still some doubts about the validity of $T$. graeffei and $T$. fusca (Haefelfinger, 1960; Kress, 1968; Ortea et al., 1989; Cervera et al., 2000; Gosliner \& Fahey, 2008). Recently, Doneddu et al. (2020) reviewed this problematic framework and analyzed the descriptions and distributions of Trapania fusca and Trapania graeffei published to date. They concluded that both species must be considered valid based on the colour pattern, attributing to $T$. fusca the single specimen described by Lafont (1874) from the Atlantic Ocean, and T. graeffe $i$ all other specimens found in the Mediterranean Sea. Because the coloration pattern and radular characters have been considered supporting features to distinguish between Trapania species (Kress, 1968; Rudman, 1987; Cervera et al., 2000; Fahey, 2004; Gosliner \& Fahey, 2008), here we agree with previous authors (Ortea et al., 1989; Cervera et al., 2000; Donnedu et al., 2020) and retain the taxonomic status of $T$. tartanella, T. graeffei and T. fusca as different species until further anatomical and molecular analyses that included these three species can be performed.
Neither Lafont (1874) nor Bergh (1881) specified in their original descriptions where, if any, type specimens of $T$. fusca and T. graeffe $i$ were deposited. We have searched for specimens of Trapania fusca in different museums around the world and contacted collaborators and citizens in order to collect new material. As for the Natural History Museums, the Muséum de Bordeaux - Sciences et nature (Bordeaux, France) has deposited some material studied by A. Lafont. However, no specimens of Trapania fusca were found among them. If the material was deposited in the Bordeaux Museum, here we consider it lost (L. Charles pers. commun.). In addition, as the original description is published in the Journal of Conchyliologie, we asked the head of conservation of the mollusc collection at the Muséum National d'Historie Naturelle in Paris, where most of the species published in that journal are deposited. Unfortunately, the type species of Trapania was not found there either. Therefore, we conclude that the type material of T. fusca does not exist. Among the divers and citizen consulted, who have decades of experience in the biodiversity of the Arcachon Bay, they indicated that $T$. fusca has not been found in the area at least since 1980 (M. Poddubetskaia pers. commun.), when they started frequenting the area. We neither found further material from other localities. The only one specimen identified as T. fusca was the one studied here, deposited in the Basel Museum (Switzerland). However, after Doneddu et al. (2020), it must be considered Trapania graeffei until proven otherwise.

In the original description of $T$. graeffei, Bergh (1881) described the radula having 51 rows of teeth. The masticatory margin has 22-24 denticles, ending in a large, pointed hook. In the specimens here studied, we counted less rows of teeth with the images taken from $\mu \mathrm{CT}$ scanning but this difference in the radular formula could be due to the resolution of $\mu \mathrm{CT}$, which seems insufficient when very small structures are studied. The large outer cusp is visible and agrees with Bergh's (1881) description. Regarding the reproductive system of $T$. graeffei, only specimens from Villefranche-surMer (France, Mediterranean coast) were detailed studied and drawn by Kress (1970, as T. fusca), whose description agrees with the specimen here studied.

Although the type species of Trapania cannot be compared with the remaining type species studied here, the synapomorphies of the genus Trapania are well defined in the literature, being the genus of the family Goniodorididae easier to distinguish. Trapania species have a reduced mantle margin. They are characterized by having a single pair of curved extra-rhinophoral and extra-branchial appendages. The rhinophores are lamellated, and the anus is surrounded by three tripinnate gill branches that form a semicircle. Trapania is the only genus of Goniodorididae with a single lateral tooth, and the jaws have elements. The penis is armed 
(Table 1) (Kress, 1968; Rudman, 1987; Gosliner \& Fahey, 2008).

Genus Goniodoridella Pruvot-Fol, 1933

Type species: Goniodoridella savignyi Pruvot-Fol, 1933 by monotype

Goniodoridella savignyi Pruvot-Fol, 1933

(Figs. 1e; 2f; 4g, h; 5d-f; and 7a-d)

Material. (QMMO 85913-85916) Australia, Queensland, Mooloolah River, La Balsa Park, 30/08/2019, collected by Gary Cobb, 96\% EtOH, (QMMO 85913) 3 mm preserved,
(QMMO 85914) $4 \mathrm{~mm}$ preserved, dissected (SEM: radula, labial cuticle, penis), (QMMO 85915) $3 \mathrm{~mm}$ preserved, dissected (SEM: radula, labial cuticle), (QMMO 85916) $3 \mathrm{~mm}$ preserved, $\mu \mathrm{CT}$ scanning.

External morphology (Fig. 1e). Preserved specimens 3-4-mm length. Body elongated, ending in long and pointed end of foot. Notal border well developed, reduced, covering body. Two elongated and conical papillae located in front of rhinophores. Along sides of body, edge of mantle serrated due to presence of small pointed tubercles, but lacking
Fig. 7 a-d Scanning electron micrographs of Goniodoridella savignyi Pruvot-Fol, 1933 (QMMO 85914) and e-h scanning electron micrographs of Murphydoris singaporensis Sigurdsson, 1991 (ZRC. MOL.15663c). a Labial cuticle. b Frontal view of rachis and internal and external teeth. c Detail of external teeth from side view. d Penial spines. e Frontal view of radula. f Frontal view of rachis and internal and external teeth. $\mathbf{g}$ Detail of internal teeth. h Penial spines. Scale bars: a $5 \mu \mathrm{m}$. b $50 \mu \mathrm{m}$. c $30 \mu \mathrm{m}$. d $20 \mu \mathrm{m}$. e $200 \mu \mathrm{m}$. f $50 \mu \mathrm{m}$. g $30 \mu \mathrm{m}$. h $50 \mu \mathrm{m}$
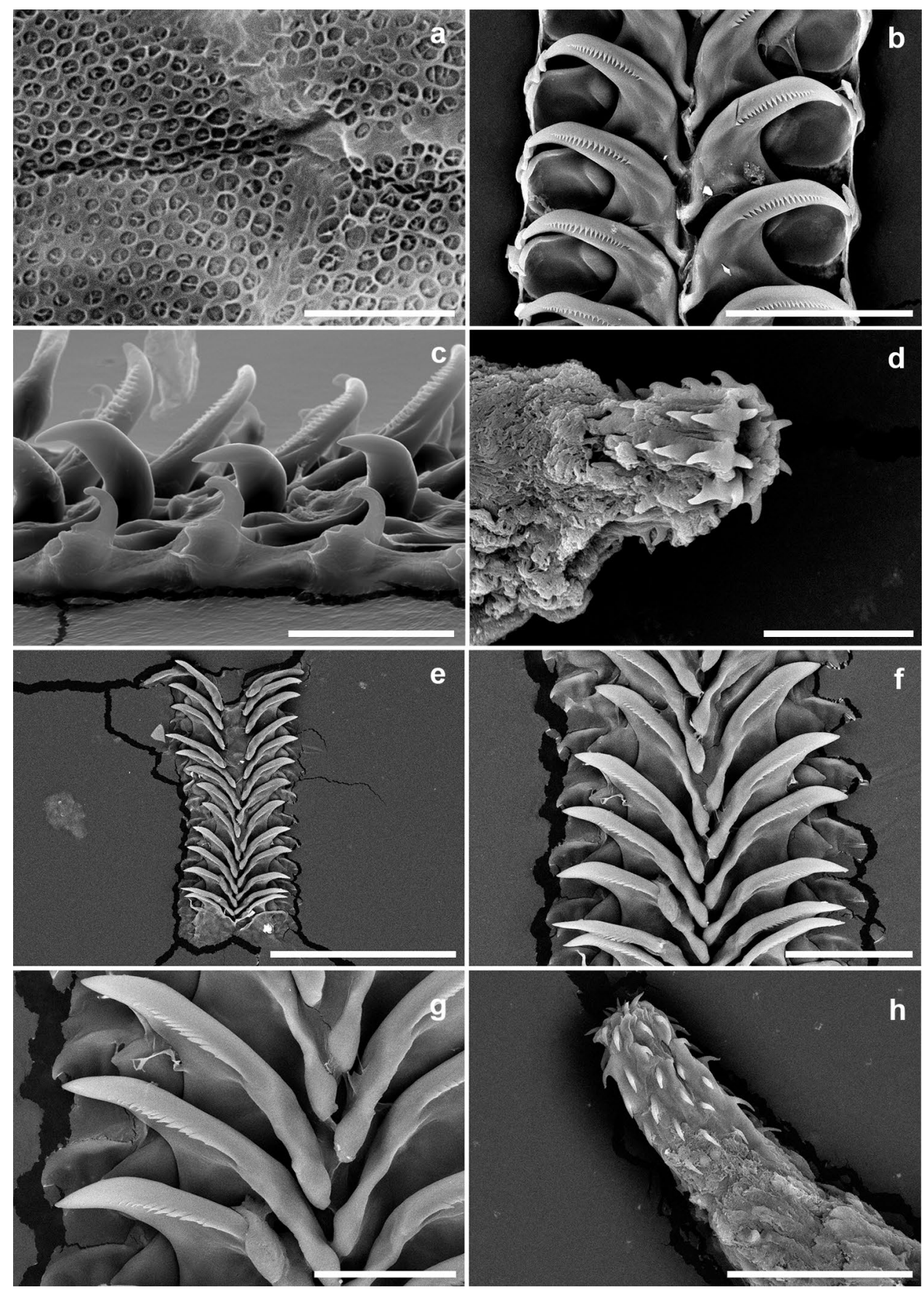
well-developed papillae. On each side of body, wide, flat and long posterior papilla extends up to the middle of tail at end of mantle. Middorsal crest of small tubercles run from behind rhinophores to gill. Rhinophores non-retractile, slender and smooth. Rhinophoral sheaths absent. Gill composed of six simple thin branches, forming semicircle around anus. Gill branches grouped in pairs, sharing stalk. Oral tentacles small and digitiform. Anterior part of foot rounded. Reproductive opening located on right lateral side of body, in first third of body.

Colour pattern (Fig. 1e). Hyaline white body with tubercles, papillae, rhinophores, gill branches and posterior end of foot tipped in yellow.

Foregut anatomy (Figs. 4g and 7a-c). Buccal bulb thick and muscular. Dorsal buccal pump rounded, expanding posteriorly (Fig. 4g). Radular sac long, ventral and expands posteriorly (Fig. 4g). Oesophagus elongated, beginning from posterior end of buccal bulb behind buccal pump. Elongated salivary glands located at junction of oesophagus with buccal bulb (Fig. 4g). Nervous system covers this junction. Oesophagus continues posteriorly and inserts into digestive gland + ovotestes complex. Stomach and oesophagus join in diffuse chamber inside digestive gland + ovotestes complex. Small, oval stomach located in left dorsal part of body. A thin and long intestine originates in stomach, and continues laterally towards right side of body. Intestine ends in dorsal, posterior anus (Fig. 4g). Thin, weak labial cuticle surrounds lips and expands within buccal pump. Labial cuticle with honeycomb-shaped cuticle elements (Fig. 7a). Radular formula $17 \times 1$ 1.1.0.1.1. Inner lateral tooth with single large cusp and wide, rectangular base (Fig. 7b). Cusp large and pointed, with masticatory margin bearing 19-25 small, thin pointed denticles (Fig. 7b). Denticles longer in middle part. Base ends in sort of prominent wing with pointed edge in upper, external part (Fig. 7b). Outer lateral tooth much smaller, curved, with large and thick cusp in upper part, followed by two rounded projections and small poorly developed cusp. Base quadrangular (Fig. 7c).

Reproductive system (Figs. 2f, 4h and 7d). Reproductive system located in anterior third of body. Thin preampullary hermaphroditic duct originates in ovotestis, located inside digestive gland + ovotestes complex. Hermaphroditic duct expands into large, oval ampulla. Narrow postampullary duct splits into two narrow ducts: oviduct duct and duct that connects with prostatic portion of vas deferens. Prostate large, wide, sausage-shaped, becomes thin and short vas deferens. Distal part of vas deferens widens into penial bulb in distal part. Penis with spines. Penial spines short, hooked, arranged in rows (Fig. 7d). Short vagina connects to large, rounded bursa copulatrix. At base of bursa continues a duct that connects with large, pyriform receptaculum seminis. Halfway to receptaculum seminis joins uterine duct. Bursa copulatrix and seminal receptacle similar in size. Uterine duct connects with female gland mass.

Spicule pattern (Fig. 5d-f). Body supported by dense network of spicules, which includes mantle, foot, gill branches, oral tentacles and rhinophores, being more concentrated and numerous in ventral part of body. Spicules elongated, wider at middle part, with sharp ends. Tubercles of mantle, gill branches and crest of mantle supported by disorganized set of spicules at base, consisting of several spicules from mantle, which join at dorsal part as a pyramid shape. Spicules at notal edge supports serrated margin, pointed outwards (Fig. 5d, e). Rhinophores with dense amount of curved, small spicules, forming tube which supports entire structure. On foot, spicules form intercalated meshwork. Spicules of foot wider and longer, arranged transversally from sides to centre (Fig. 5f).

Remarks The genus Goniodoridella Pruvot-Fol, 1933 was first described highlighting as diagnostic characteristics the presence of two extra-branchial claviform processes on the back of the gills, small and conical appendages in front of the rhinophores and a slight crest in the midline of the mantle (Pruvot-Fol, 1933). We were not able to find specimens collected near the type locality, Gulf of Suez (Egypt) (Pruvot-Fol, 1933). However, G. savignyi has been reported widespread in Indo-Pacific waters and seems to be common in Australia (Baba, 1960; Willan \& Coleman, 1984; Rudman \& Darvell, 1990; Rudman, 1998; Burn, 2006; Su et al., 2009; Martynov et al., 2015; Gosliner et al., 2018), where the specimens here studied are from.

In the original description, Pruvot-Fol (1933) did not clarify the coloration of specimens, stating that the specimen studied from the Suez Canal did not have indications of colour ("un individu sans indications de coloration"). However, in the next paragraph, the author also mentioned that the colour was black ("de couleur sombre"). In following publications, the general body colour of G. savignyi appears whitish with yellow patches on the middorsal crest and mantle edge, tip of rhinophores and posterior branchial processes yellow and may yellow tip of gill branches (Baba, 1960). This colour pattern is also found in several publications reporting the species (Willan \& Coleman, 1984; Rudman \& Darvell, 1990; Rudman, 1998; Burn, 2006; Su et al., 2009; Martynov et al., 2015; Gosliner et al., 2018).

The specimens here studied match with the original description having smooth rhinophores and simple gill branches, one small, conical papilla in front of each rhinophore and one claviform papilla behind the gill (Pruvot-Fol, 1933). Moreover, G. savignyi has a serrated mantle margin and a middorsal crest (Pruvot-Fol, 1933). Pruvot-Fol (1933) described the radular formula 1.1.0.1.1, but did not indicate the number of rows, neither detailed the shape of external teeth due to the small size. Afterwards, Baba (1960) found 
G. savignyi in Japanese waters and described more details of the gill, having three bipinnate branches, and the radular formula with $12-18$ rows of teeth.

Despite the fact that G. savignyi has been found and reported by numerous authors (Baba, 1960; Willan \& Coleman, 1984; Rudman \& Darvell, 1990; Rudman, 1998; Burn, 2006; Su et al., 2009; Gosliner et al., 2018; Martynov et al., 2015), the anatomy of its reproductive system has not been described previously. Here we include for first time scanning electron microscope photographs of its radula, penis and labial cuticle and a detailed description of its reproductive system.

Currently, the genus Goniodoridella only includes two species, G. savignyi and G. borealis Martynov, Sanamyan \& Korshunova, 2015. G. borealis was described as different species according to the colour and details of the dorsal processes. However, its coloration is transparent whitish with light and dark yellow on the dorsal crest, mantle edge, rhinophores, gill branches and anterior and posterior papillae (Martinov et al., 2015a), as well as in G. savignyi. Also, G. borealis has discrete lamellae on the rhinophores and the radula formula is $15 \times 1.1 .0 .1 .1$ while the rhinophores of $G$. savignyi are smooth and the radula formula is 12-18 ×1.1.0.1.1 (Baba, 1960; Martynov et al., 2015). Despite the probability of existence of species complex within G. savignyi (Martynov et al., 2015), further molecular studies would be needed to ensure the difference between these species due to the highly similar anatomical features.

The genus Goniodoridella is characterized by having a mantle edge marked by spicules, giving a serrated crest appearance, but without papillae. It has claviform extrabranchial processes behind the gill and small, conical appendages in front of the rhinophores. The rhinophores can be lamellated or smooth; the anus is surrounded by a variable number of simple gill branches forming a semicircle around the anus. The radula formula is $\mathrm{N} \times 1.1 .0 .1 .1$ (Table 1) (Pruvot-Fol, 1933; Baba, 1960; Martynov et al., 2015).

Genus Murphydoris Sigurdson, 1991

Type species: Murphydoris singaporensis Sigurdsson, 1991 by monotypy

Murphydoris singaporensis Sigurdsson, 1991

(Figs. 1f; 2g; 4i, j; and 7e-h)

Material. Paratype (ZRC.MOL.15663). Singapore, Buloh, mangroves between Kranji and Sungei Rivers, three specimens, 15/04/1987, collected by J. B. Sigurdsson. One specimen scanned under $\mu$ CT (ZRC.MOL.15663a), one specimen dissected (ZRC.MOL.15663c).

External morphology and colour pattern (Fig. 1f). Described in detail in the original description by Sigurdson (1991).
Foregut anatomy (Figs. $4 \mathrm{i}$ and $7 \mathrm{e}-\mathrm{g}$ ). Buccal bulb is described and drawn by Sigurdson (1991: 262, Fig. 1d). Oesophagus continues posteriorly and inserts into digestive gland + ovotestes complex. Stomach and oesophagus meet in diffuse chamber inside digestive gland + ovotestes complex. Small, oval stomach located in left dorsal part of body. Thin and long intestine begins in stomach, continuing laterally towards right side of body and ends in dorsal, posterior anus (Fig. 4i). Labial cuticle smooth. Radular formula $14 \times 1$ 1.1.0.1.1. Inner lateral tooth with single large, thin cusp and wide, rectangular base (Fig. 7e-g). Cusp large and pointed. Masticatory margin bears 9-11 small, pointed denticles (Fig. 7e-g). Posterior end of cusp well developed, ending in a sort of prominent wing with pointed edge (Fig. 7e-g). Outer lateral tooth much smaller, with two pointed cusps, upper one thinner and more pointed than lower one (Fig. $7 \mathrm{e}-\mathrm{g}$ ).

Reproductive system (Figs. $2 \mathrm{~g}, 4 \mathrm{j}$ and $7 \mathrm{~h}$ ). Reproductive system small, located in anterior third of body. Thin preampullary hermaphroditic duct originates in ovotestis, located within digestive gland + ovotestes complex. Hermaphroditic duct expands in small, oval ampulla. Short postampullary duct divides into oviduct duct and prostatic portion of vas deferens. Prostate starts as narrow duct and then expands in wide elongate sac. Prostate narrows and continues as vas deferens, ending in penis. Penis with hooked spines, similar in shape and size of spines along penis (Fig. 7h). Vagina short and narrow, connects with large and rounded bursa copulatrix. At base of bursa copulatrix, thin duct joins smaller, oval receptaculum seminis. Uterine duct emerges from female gland mass and connects at base of receptaculum seminis.

Spicule pattern. The $\mu \mathrm{CT}$ scan did not show a marked spicule pattern. Some spicules were seen scattered through the layers but we were not able to obtain clear photographs of them. Sigurdson (1991) described the body wall with numerous spicules which disappeared in preserved specimens. Swennen and Buatip (2012) found spicules elsewhere in the skin, including the foot.

Remarks. The genus Murphydoris Sigurdsson, 1991 only includes one species, Murphydoris singaporensis Sigurdsson, 1991, originally described from Singapore. Murphydoris was proposed as a new genus mainly distinguished by the lack of lamellae in the rhinophores and dorsal gill surrounding the anus (Sigurdsson, 1991; Swennen \& Buatip, 2012). Sigurdsson (1991) described the species as having a reduced mantle edge, with a small upstanding ridge, some appendages located on the posterior part of the body, radular formula $\mathrm{N} \times 1$ 1.1.0.1.1 and armed penis (Sigurdsson, 1991; Swennen \& Buatip, 2012). To date, the 
only available photographs of this species were published by Swennen and Buatip (2012) based on specimens collected in Thailand. These authors also provided a complete anatomical description of the species.

Here we fully describe the type material of the monotypic species of the genus for the first time, showing pictures of the specimens and scanning electron microscope photographs of the radula, labial cuticle and penis. The study of the paratypes allowed us to find some differences with the original description. Sigurdsson (1991) described the species as follows: "Mantle edges form two low ridges starting slightly in front of and to the sides of the rhinophores; these extend backwards, each ending in three bifid to trifid papillae on each side of anus, behind which the ridges join to form a median metapodial ridge. There are no peri-anal ctenidia". However, we have observed that these three bifid or trifid papillae are, in fact, a tripinnate gill. It constitutes one gill branch located at the posterior part of the mantle edge. This position of the gill is characteristic of Murphydoris within Goniodorididae family. Thus, the body of this species lacks papillae.

Regarding the reproductive system of the species, in overall the description and drawing of Swennen and Buatip (2012) match with the paratypes. However, we found some differences in the female part. Swennen and Buatip (2012) described a long receptaculum seminis and drawn this structure arising from the vagina, followed by a small and rounded bursa copulatrix, which also emerges from the vagina. In the paratypes, we observed that the vagina is connected with a rounded bursa copulatrix. At the base of the bursa emerges a second duct that connects to a smaller, oval receptaculum seminis. Near the base of the receptaculum seminis the uterine duct arises. These differences could be due to the interpretation of the drawing since Swennen and Buatip (2012) did not describe the connections in the main text of the article. Here we describe in detail the internal anatomy of the species, being important to clarify the morphology of the different structures and the connections between them since it has taxonomic importance for the characterization of the species.

The study of the paratype of Murphydoris singaporensis allowed us to conclude that the genus is characterized by having a reduced mantle margin, lacking dorsal or lateral papillae. The rhinophores are smooth, and it is the only genus characterized by having the gill branches located at the posterior end of the mantle margin, instead surrounding the anus. The radula has one inner and one outer lateral tooth, with an armed labial cuticle (Table 1). Moreover, the species also have a muscular thickening of the oesophagus, described by Sigurdsson (1991) as oesophagal pump. This structure has been only described in the present species, and it could be a synapomorphy of the genus.

\section{Discussion}

Micro-CT has been used to study the anatomy of different groups of molluscs, giving important information to the taxonomic and phylogenetic knowledge of species (Handschuh et al., 2013; Candás et al., 2016; Palmer et al., 2017; Marcondes Machado et al., 2019). The advantages of this tool include the study of the taxonomic characteristics of small specimens while maintaining the integrity of rare animals, the possibility of discovering new diagnostic characteristics and the examination of organs in their natural position (Faulwetter et al., 2014; Marcondes Machado et al., 2019). However, there are still limitations in the ability to distinguish organs of similar density and lack of resolution for the visualization of small structures (Marcondes Machado et al., 2019), such as the radula, labial cuticles and penial spines in our specimens. Therefore, to date, the combination of micro-CT scanning with traditional techniques as dissections and scanning electron microscope is the best way to study small nudibranchs.

The family Goniodorididae belongs to the superfamily Onchidoridoidea Gray, 1827, which includes five families: Onchidorididae Gray, 1827; Goniodorididae H. Adams \& A. Adams, 1854; Corambidae Bergh, 1871; Calycidorididae Roginskaya, 1972; and Akiodorididae Millen \& Martynov, 2005 (Hallas \& Gosliner, 2015). The superfamily has been characterized by the presence of a buccal pump, gathering the different families into Suctoria (Valdés \& Bouchet, 1998; Millen \& Martynov, 2005; Hallas \& Gosliner, 2015). The shape of the inner lateral teeth is also shared in Onchidoridoidea families, with hook-shaped inner lateral teeth, with the exception of Akiodorididae (Millen \& Martynov, 2005; Hallas \& Gosliner, 2015). Moreover, the spicules show a common pattern in families Goniodorididae and Onchidorididae, having overlapped sheets of spicules in the mantle and the tubercles are supported by spicule mounds (Penney et al., 2018; Paz-Sedano et al., 2021). Regarding the family Goniodorididae, the spicule pattern has been studied in species Okenia rosacea and Lophodoris danielsseni, in addition to the specimens of Goniodoris nodosa and Goniodoridella savignyi here included (Penney et al., 2018; Paz-Sedano et al., 2021). Due to the shared pattern among genera, as well as the presence or absence of spicules within a same genus (e.g. the presence of spicules in $O$. rosacea but the lack of spicules in $O$. elegans), the spicule pattern seems to be a taxonomic characteristic at the superfamily level. The evolution of this feature within the superfamily cannot be known until further species are studied and phylogenetic relationships among species and genera are clarified.

Goniodorididae is characterized by having a generally reduced mantle margin, the body may present dorsal and/ 
or lateral papillae, rhinophores are lamellated or smooth, the anus is dorsal and often surrounded by gill branches and the radula formula may be 1.0.1, 1.1.0.1.1, 1.1.1.1.1. The jaws are weak or absent, and they feed on ascidians and bryozoans. The receptaculum seminis connects adjacent to or on the uterine duct (Thompson \& Brown, 1984; Edmunds \& Just, 1985; Gosliner, 2004; Rudman, 2004; Gosliner \& Fahey, 2008; Swennen \& Buatip, 2012; Hallas \& Gosliner, 2015; Edmunds, 2009). However, the features of each genus seem to be unclear, since several undescribed species can be found in field guides ascribed to different genera. For instance, Murphydoris sp. in Coleman (2008: 295) is identified as Goniodoridella sp. 1 in Debelius and Kuiter (2007: 29). Also, Goniodoridella sp. 3 by Nakano (2018: 166) is identified as Goniodoris aspersa Alder \& Hancock, 1846 by Debelius \& Kuiper (2007: 28).
Regarding the external similarities that may confuse the identification of species between Goniodorididae genera, we could group them into three groups, (1) Goniodoris and Lophodoris, which have a broad mantle margin; (2) Ancula, Trapania and Spahria, which have a cylindrical body shape, and (3) Okenia, Goniodoridella and Murphydoris, which have a reduced mantle margin.

Goniodoris and Lophodoris lack dorsal or lateral papillae, the rhinophores are lamellated and have several gill branches around the anus and the radular formula is $N \times 1.1 .0 .1 .1$ (Table 1; Fig. 8) (Friele \& Hansen, 1876; Wägele \& Cervera, 2001; Ekimova et al., 2019; Paz-Sedano et al., 2021). However, only Lophodoris has long, strong spicules, and a dorsal crest (Table 1; Fig. 8) (Friele \& Hansen, 1876; Marcus \& Marcus, 1970; Paz-Sedano et al., 2021). Ancula, Spahria and Trapania share the presence of appendages in front of the rhinophores, which are lamellated (Table 1; Fig. 8) (Risbec, 1928;

\section{Dichotomous key}

1. Broad mantle margin ....2

- Absence or reduced mantle margin ....3

2. Presence of strong spicules supporting a dorsal and mantle crest, lack dorsal and lateral papillae, radular formula $\mathrm{N} \times 1$ 1.1.0.1.1... Lophodoris

- Absence of dorsal and mantle crest, lack dorsal and lateral papillae, radulaı formula $\mathrm{N} \times 1.1 .0 .1 .1 \ldots$ Goniodoris

3. Absence of mantle margin, giving a cylindrical body shape .... 4

- Presence of reduced mantle margin .... 6

4. Prsence of extra-branchial and extra-rhinophoral appendages .... 5

- Absence of extra-branchial appendages, two extra-rhinophoral appendages, radular formula $\mathrm{N} \times 2 \cdot 1 \cdot 0.1 .2 \ldots$. Spahria

5. Several extra-branchial appendages forming a circle around the gill, two extra-rhinophoral appendages, radular formula N x 1.1.1.1.1 ... Ancula

- Two extra-branchial appendages forming a circle around the gill, two extra-rhinophoral appendages, radular formula $\mathrm{N} \times 1.0 .1 \ldots$. Trapania

6. Presence of lateral and/or dorsal papillae 7

- Absence of lateral and dorsal papillae, gill branches located at the end of the notal edge, on each side of the anus, radular formula $\mathrm{N} \times 1.1 .0 .1 .1$ .... Murphydoris

7. Two conical lateral papillae in front of the rhinophores, several near the gill branches, rhinophores lamellated or smooth, radular formula $\mathrm{N} \times 1.1 .0 .1 .1 \ldots$ Goniodoridella

- Several lateral papillae around the entire mantle edge, may have dorsal papillae, rhinophores always lamellated, radular formula $\mathrm{N} \times 1.1 .0 .1 .1 \ldots$ .... Okenia

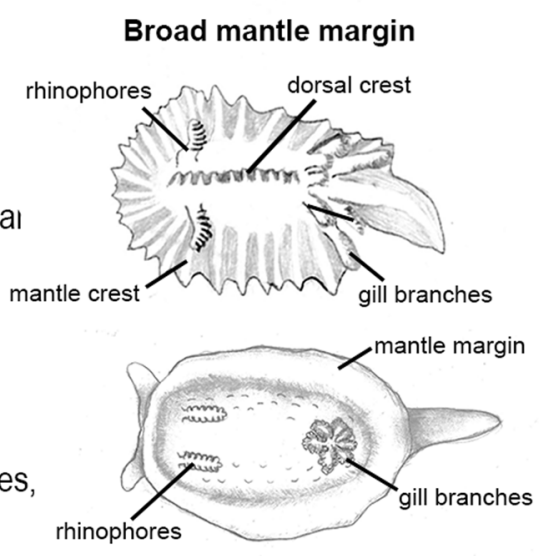

Absence or reduced mantle margin

cylindrical body

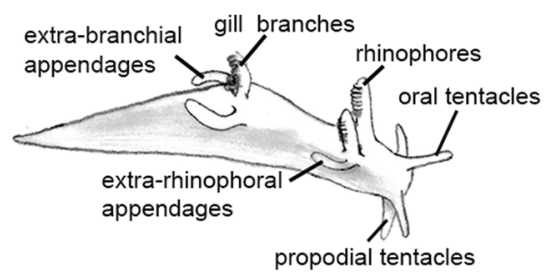

reduced mantle margin

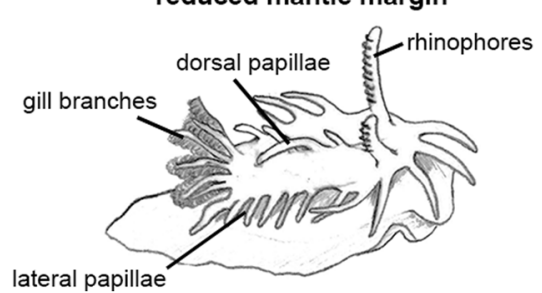

Fig. 8 Dichotomous key of Goniodorididae genera 
Thompson \& Brown, 1984; Baba, 1990; Gosliner \& Fahey, 2008). However, Spahria lacks extra-branchial appendages (Risbec, 1928), Ancula has several extra-branchial appendages forming a circle around the gill (Baba, 1990) and Trapania has only two (Gosliner \& Fahey, 2008). Internally, the radular formula is also different, with $\mathrm{N} \times 1$ 1.1.1.1.1, $\mathrm{N} \times 2.1 .0 .1 .2$ and $\mathrm{N} \times 1.0 .1$ for Ancula, Spahria and Trapania, respectively (Table 1; Fig. 8) (Risbec, 1928; Thompson \& Brown, 1984; Baba, 1990; Gosliner \& Fahey, 2008). The most problematic group may be the one including Okenia, Goniodoridella and Murphydoris. All three genera were described with a reduced mantle margin with lateral papillae and radular formula N $\times$ 1.1.0.1.1 (Pruvot-Fol, 1933; Sigurdsson, 1991; Gosliner, 2004; Rudman, 2004; Swennen \& Buatip, 2012; Martynov et al., 2015). However, Okenia may have papillae around the entire mantle edge and dorsal papillae, while Goniodoridella has two lateral papillae in front of the rhinophores and several near the gill branches (Pruvot-Fol, 1933; Gosliner, 2004). Okenia has lamellated rhinophores (Gosliner, 2004), while in Murphydoris rhinophores are smooth (Swennen \& Buatip, 2012). In addition, our study of Murphydoris singaporensis paratypes allowed us to observe that the appendices located on each side of the anus, at the end of the notal edge, are gill branches. Therefore, the species lack dorsal and lateral papillae. This characteristic is unique to Murphydoris and, together with its smooth rhinophores and its body shape, allows to distinguish this genus from other Goniodorididae (Table 1; Fig. 8).

Despite the possibility that future studies including more species of Goniodorididae could recover some synonymized genera, our results attempt to facilitate the identification of each current valid genera, the assignment of species to each genus and future morphological comparisons.

Acknowledgements Thanks to Irine Ekimova for her donations of specimens of Ancula gibbosa and Goniodoris nodosa, and Gary Cobb for his great disposition sampling new material of Goniodoridella savignyi. Many thanks to Manuel Malaquias and Cessa Rauch for Ancula gibbosa and Goniodoris nodosa specimens obtained during the project "The sea slugs of Southern Norway: diversity, barcoding, and invasive species", funded by the Norwegian Taxonomy Initiative, Artsdatabanken, Project No. 812038 (PI: M. A. E. Malaquias). We thank the Museo Nacional de Ciencias Naturales (Madrid, Spain), and the Naturhistorisches Museum Basel (Switzerland) for lending us specimens of Okenia elegans and Trapania graeffei, respectively. Our special thanks to the Lee Kong Chian Natural History Museum of Singapore (Singapore) for allowing us to study the paratypes of Murphydoris singaporensis in depth and without any restrictions.

Funding Open Access funding provided thanks to the CRUE-CSIC agreement with Springer Nature. This study was partially supported by the Systematics Research Fund. Morphological analyses were partially funded by Systematics Research Fund (SRF) (the Linnean Society and the Systematics Association).

Availability of data and material (data transparency) Specimens are deposited at Lee Kong Chian Natural History Museum of Singapore (Singapore); Museo Nacional de Ciencias Naturales, Madrid (Spain);
Australian Museum (Australia); Zoology Museum of Bergen University (Norway); and Naturhistorisches Museum Basel (Switzerland). Images and rotational movies obtained under microcomputed tomography are available on MorphoBank.

Code availability Not applicable.

\section{Declarations}

Ethics approval Not applicable.

Consent to participate Approved by all coauthors.

Consent for publication Approved by all coauthors.

Conflict of interest The authors declare no competing interests.

Open Access This article is licensed under a Creative Commons Attribution 4.0 International License, which permits use, sharing, adaptation, distribution and reproduction in any medium or format, as long as you give appropriate credit to the original author(s) and the source, provide a link to the Creative Commons licence, and indicate if changes were made. The images or other third party material in this article are included in the article's Creative Commons licence, unless indicated otherwise in a credit line to the material. If material is not included in the article's Creative Commons licence and your intended use is not permitted by statutory regulation or exceeds the permitted use, you will need to obtain permission directly from the copyright holder. To view a copy of this licence, visit http://creativecommons. org/licenses/by/4.0/.

\section{References}

Abdelkrim, J., Aznar-Cormano, L., Fedosov, A. E., Kantor, Y. I., Lozouet, P., Phuong, M. A., Zaharias, P., \& Puillandre, N. (2018). Exon-capture-based phylogeny and diversification of the venomous gastropods (Neogastropoda, Conoidea). Molecular Biology and Evolution, 35(10), 2355-2374. https://doi.org/ 10.1093/molbev/msy144

Abraham, P. S. (1877). Revision of the anthobranchiate nudibranchiate Mollusca, with descriptions or notices of forty-one hitherto undescribed species. Proceedings of the Zoological Society of London, 196-269.

Alder, J. (1841). Observations on the genus Polycera of Cuvier, with descriptions of two new British species. Annals \& Magazine of Natural History, 6(38), 337-342.

Alder, J., \& Hancock, A. (1845). Monograph of the British nudibranchiate Mollusca: With figures of all the species. Ray Society.

Baba, K. (1935). Nudibranchia of Mutsu Bay. Science Reports of the Tohoku Imperial University, 10(4), 331-336.

Baba, K. (1960). The genera Okenia, Goniodoridella and Goniodoris from Japan (Nudibranchia-Goniodorididae). Publications of the Seto Marine Biological Laboratory, 8(1), 79-83. http://hdl.handle.net/2433/174698

Baba, K. (1990). Notes on the rare genera Trapania and Ancula from Japan with the description of a new species (Nudibranchia: Goniodorididae). Venus 49(1): 8-18. https://doi.org/10.18941/ venusjjm.49.1_8

Bergh, R. (1881). Beitrage zu einer Monographic der Polyceraden. II. Verhandlungen Der Zoologisch-Botanischen Gesellschaft in Wien, 30, 629-668. 
Bouchet, P., \& Ortea, J. (1983). A New Hopkinsia Feeding on Bryozoa in the South Pacific: Mollusca: Opisthobranchia. Venus (Japanese Journal of Malacology), 42(3), 227-233

Bouchet, P., \& Tardy, J. (1976). Faunistique et biogeographie des nudibranches des côtes françaises de l'Atlantique et de la manche. Annales De L'institut Oceanographique, 52(2), 205-213.

Burn, R. (1961a). Drepaniella mapae gen. et spec. nov., a new goniodorid nudibranch from south eastern Australia. The Veliger, 3(4), 102-104.

Burn, R. (1961b). Eucrairia nom. nov. for Drepaniella Burn. Veliger, 4(1): 51.

Burn, R. (2006). A checklist and bibliography of the Opistobranchia (Mollusca: Gastropoda) of Victoria and the Bass Strait area, south-eastern Australia. Museum Victoria Science Reports, 10, $1-42$.

Candás, M., Díaz-Agras, G., Abad, M., Baniol, L., Cunha-Veira, X., Pedrouzo, L., Señaris, M. P., Tato, R., García-Álvarez, Ó., \& Urgorri, V. (2016). Application of micro-CT in the study of the anatomy of small marine molluscs. Microscopy and Analysis, 30, S8-S11.

Carmona, L., \& Wilson, N. G. (2018). Two new species of the tropical facelinid nudibranch Moridilla Bergh, 1888 (Heterobranchia: Aeolidida) from Australasia. Records of the Western Australian Museum, 33(1), 95-102. https://doi.org/10.18195/issn.03123162.33(1).2018.095-102

Cervera, J. L., López-González, P. J., \& García-Gómez, J. C. (1991). Taxonomic and geographical range data on two rare species of Okenia (Gastropoda: Nudibranchia: Doridacea) from the Eastern Atlantic. The Veliger, 34(1), 56-66.

Cervera, J. L, García-Gómez, J. C., \& Megina, C. (2000). A new species of Trapania Pruvot-Fol, 1931 from the Bay of Cadiz. With remarks on other Trapania species: (Nudibranchia: Goniodorididae). Ophelia, 52(1), 17-24. https://doi.org/10.1080/00785236. 1999.10409416

Cervera, J. L., Calado, G., Gavaia, C., Malaquias, M. A. E., Templado, J., Ballesteros, M., García-Gómez, J. C., \& Megina, C. (2004). An annotated and updated checklist of the opisthobranchs (Mollusca: Gastropoda) from Spain and Portugal (including islands and archipelagos). Boletín Del Instituto Español De Oceanografía, 20(1-4), 1-122.

Chughtai, K., Song, Y., Zhang, P., Derstine, B., Gatza, E., Friedman, J., Hully, L., Inglis, C., Goldstein, S., Magenau, J., Pawarode, A., Reddy, P., Riwes, M., Yanik, G., Wang, S. C., \& Choi, S. W. (2016). Analytic morphomics: A novel CT imaging approach to quantify adipose tissue and muscle composition in allogeneic hematopoietic cell transplantation. Bone Marrow Transplantation, 51, 446-450. https://doi.org/10.1038/bmt.2015.267

Coleman, N. (2008). Nudibranchs encyclopedia, catalogue of Asial Indo-Pacific sea slugs. Neville Coleman's Underwater Geographic Pty Ltd.

deWaard, J. R., Ratnasingham, S., Zakharov, E. V., Borisenko, A. V., Steinke, D., Telfer, A. C., Perez, K. H. J., Sones, J. E., Young, M. R., Levesque-Beaudin, V., Sobel, C. N., Abrahamyan, A., Bessonov, K., Blagoev, G., deWard, S. L., Ho, C., Ivanova, N. V., Layton, K. K. S., Lu, L., Manjunath, R., McKeown, J. T. A., Milton, M. A., Miskie, R., Monkhouse, N., Naik, S., Nikolova, N., Pentinsaari, M., Prosser, S. W. J., Radulovici, A., Steinke, C., Warne, C. P., \& Hebert, P. D. N. (2019). A reference library for Canadian invertebrates with 1.5 million barcodes, voucher specimens, and DNA samples. Scientific Data, 6(1), 1-12. https://doi. org/10.1038/s41597-019-0320-2

Debelius. H., \& Kuiter, R. H. (2007). Nudibranchs of the world. Ikan-Unterwasserarchiv.

Doneddu, M., Trainito, E., \& Furfaro, G. (2020). Trapania graeffei (Bergh, 1881) (Gastropoda, Nudibranchia) is a valid Mediterranean species. Bollettino Malacologico, 56, 86-90.
Edmunds, M. (2009). Opisthobranchiate Mollusca from Ghana: Goniodorididae. Journal of Conchology, 40(1), 37.

Edmunds, M., \& Just, H. (1985). Dorid, Dendrodorid and Arminid nudibranchiate mollusca from Barbados. Journal of Molluscan Studies, 51, 52-63.

Ekimova, I. A., Schepetov, D. M., Chichvarkhina, O. V., \& Chichvarkhin, A. Y. (2016). Nudibranch molluscs of the genus Dendronotus Alder et Hancock, 1845 (Heterobranchia: Dendronotina) from Northwestern Sea of Japan with description of a new species. Invertebrate Zoology, 13(1), 15-42.

Ekimova, I. A., Antokhina, T. I., \& Schepetov, D. M. (2019). "Invasion” in the Russian Arctic: Is global Climate Change a real driver? A remarkable case of two nudibranch species. Ruthenica, 29(2), 103-113.

Evertsen, J., \& Bakken, T. (2005). Nudibranch diversity (Gastropoda, Heterobranchia) along the coast of Norway. Fauna Norvegica, $25,1-37$.

Fahey, S. J. (2004). A new species of Trapania (Nudibranchia: Gonodorididae) from Western Australia with comparisons to other Indo-West Pacific Trapania. Zootaxa, 514(1), 1-12.

Faulwetter, S., Dailianis, T., Vasileiadou, K., Kouratoras, M., \& Arvanitidis, C. (2014). Can micro-CT become an essential tool for the 21 st century taxonomist? An evaluation using marine polychaetes. Microscopy and Analysis, 28, S9-S11.

Fedosov, A., Puillandre, N., \& Achaz, G. (2019). Revisiting use of DNA characters in taxonomy with MolD - a tree independent algorithm to retrieve diagnostic nucleotide characters from monolocus datasets. bioRxiv, 838151. https://doi.org/10.1101/ 838151

Forbes, E. (1840). On some new and rare British Mollusca. Annals and Magazine of Natural History, 5(29), 102-108.

Forbes, E., \& Goodsir, J. (1839). Notice of zoological researches in Orkney and Shetland during the month of June 1839. Athenaeum, $618,647$.

Forbes. E., \& Hanley, S. C. T. (1853). A history of British Mollusca, and their shells (Vol. 1).

Friele. H., \& Hansen, G. A. (1876). Bidrag til kundskaben om de norske Nudibranchier. Videnskabs-Selskabet Forhandlinger. Christiania, 69-80.

García-Gómez, J. C., Cervera, J. L., García, F. J., Ortea, J. A., GarciaMartin, S. F., Medina, A., \& Burnay, L. P. (1991). Resultados de la campaña internacional de biología marina «Algarbe-88»: Moluscos opistobranquios. Bolletino Malacologico, 27(5-9), $125-138$.

García-Melo, J. E., Oliveira, C., Silva, G. J. D. C., Ochoa-Orrego, L. E., Pereira, L. H. G., \& Maldonado-Ocampo, J. A. (2019). Species delimitation of neotropical Characins (Stevardiinae): Implications for taxonomy of complex groups. PLoS One, 14(6), e0216786. https://doi.org/10.1371/journal.pone.0216786

Goddard, J. H. R., Gosliner, T. M., \& Pearse, J. S. (2011). Impacts associated with the recent range shift of the aeolid nudibranch Phidiana hiltoni (Mollusca, Opisthobranchia) in California. Marine Biology, 158, 1095-1109. https://doi.org/10.1007/ s00227-011-1633-7

Goodheart, J. A., \& Wägele, H. (2020). Phylogenomic analysis and morphological data suggest left-right swimming behavior evolved prior to the origin of the pelagic Phylliroidae (Gastropoda: Nudibranchia. Organisms Diversity \& Evolution, 20, 657-667. https://doi.org/10.1007/s13127-020-00458-9

Gosliner, T. M. (2004). Phylogenetic systematics of Okenia, Sakishimaia, Hopkinsiella and Hopkinsia (Nudibranchia: Goniodorididae) with descriptions of new species from the tropical IndoPacific. Proceedings of the California Academy of Sciences, 5, $125-161$

Gosliner, T. M., \& Fahey, S. J. (2008). Systematics of Trapania (Mollusca: Nudibranchia: Goniodorididae) with descriptions of 16 
new species. Systematics and Biodiversity, 6(1), 53-98. https:// doi.org/10.1017/S1477200007002587

Gosliner, T. M., Valdés, Á., \& Behrens, D. (2018). Nudibranch \& sea slug identification - Indo-Pacific. New World Publications.

Haefelfinger, H. R. (1960). Neue und wenig bekannte Opisthobranchier der Gattung Trapania und Caloria aus der Bucht von Villefranche-sur-Mer. Revue Suisse Goal, 67, 226-238.

Hallas, J. M., \& Gosliner, T. M. (2015). Family matters: The first molecular phylogeny of the Onchidorididae Gray, 1827 (Mollusca, Gastropoda, Nudibranchia). Molecular Phylogenetics and Evolution, 88, 16-27. https://doi.org/10.1016/j.ympev.2015.03.015

Handschuh, S., Baeumler, N., Schwaha, T., \& Ruthensteiner, B. (2013). A correlative approach for combining microCT, light and transmission electron microscopy in a single 3D scenario. Frontiers in Zoology, 10, 44. https://doi.org/10.1186/1742-9994-10-44

Hoffmann, R., Schultz, J. A., Schellhorn, R., Rybacki, E., Keupp, H., Garden, S. R., Lemanis, R., \& Zachow, S. (2014). Non-invasive imaging methods applied to neo- and paleo-ontological cephalopod research. Biogeosciences, 11, 2721-2739. https://doi.org/ 10.5194/bg-11-2721-2014

Hołyński, R. B. (2008). Taxonomy crisis, biodiversity disaster - And sabotaging regulations. Munis Entomology \& Zoology Journal, $3(1), 1-6$.

Ihering, H. (1886). Beitrage zur Kenntniss der Nudibranchien des Mittelmeeres. II. 4. Die Polyceraden. Malakozoologische Blätter, $8,12-48$.

Johnston, G. (1838). Miscellanea zoologica. Annals and Magazine of Natural History, 1(1), 44-56.

Korshunova, T., Martynov, A., Bakken, T., \& Picton, B. (2017). External diversity is restrained by internal conservatism: New nudibranch mollusc contributes to the cryptic species problem. Zoologica Scripta, 46(6), 683-692. https://doi.org/10.1111/zsc. 12253

Kress, A. (1968). Trapania pallida sp. nov. (Opisthobranchia, Gastropoda), a genus new to Britain. Journal of Molluscan Studies, 38(2), 161-165. https://doi.org/10.1093/oxfordjournals.mollus. a065034

Kress, A. (1970). A new record of Trapania pallida (Opisthobranchia, Gastropoda) with a description of its reproductive system and a comparison with T. fusca. Journal of Molluscan Studies, 39(2-3), 111-116. https://doi.org/10.1093/oxfordjournals.mollus.a065085

LaFont, A. (1874). Description d'un nouveau genre de nudibranche des côtes de France. Journal De Conchyliologie, 3(22), 369-370.

Lemer, S., Bieler, R., \& Giribet, G. (2019). Resolving the relationships of clams and cockles: Dense transcriptome sampling drastically improves the bivalve tree of life. Proceedings of the Royal Society, 286(1896), 20182684. https://doi.org/10.1098/rspb.2018. 2684

Leuckart, F. S. (1828). Breves animalium quorundam maxima ex parte marinorum descriptiones. Heidelbergae: Typis A. Osswaldi.

Lloyd, H. M. (1952). A study of the reproductive system of some ophistobranchiate molluscs. PhD Thesis, University of London.

Lovén, S. L. (1846). Index molluscorum litora Scandinaviae occidentalia habitantium. Öfversigt Af Kongl. Vetenskaps Akademiens Forhandlinger, 3(5), 135-160.

MacFarland, F. M. (1905). A preliminary account of the Dorididae of Monterey Bay, California. Proceedings of the Biological Society of Washington, 18, 35-54.

MacFarland, F. (1966). Studies of opisthobranchiate mollusks of the Pacific Coast of North America. Memoirs of the California Academy of Science, 6.

Marcondes Machado, F., Passos, F. D., \& Giribet, G. (2019). The use of micro-computed tomography as a minimally invasive tool for anatomical study of bivalves (Mollusca: Bivalvia). Zoological Journal of the Linnean Society, 186(1), 46-75. https://doi.org/ 10.1093/zoolinnean/zly054
Marcus, Er. (1961). Opisthobranch mollusks from California. Veliger, 3(Suppl.), 1-84.

Marcus, Ev. (1972). On some opisthobranchs from Florida. Bulletin of Marine Science, 22(2), 284-308.

Marcus, Er., \& Marcus, Ev. (1970). Opisthobranchs from Curaçao and faunistically related regions. Studies on the Fauna of Curaçao and Other Caribbean Islands, 33(1), 1-129.

Martynov, A. V, Sanamyan, N. P., \& Korshunova, T. A. (2015). New data on the opisthobranch molluscs (Gastropoda: Opisthobranchia) of waters of Commander Islands and Far-Eastern seas of Russia. Conservation of biodiversity of Kamchatka and coastal waters (Proceedings of XV international scientific conference Petropavlovsk-Kamchatsky). Petropavlovsk-Kamchatsky, Russia.

Martynov, A. V., \& Schrödl, M. (2011). Phylogeny and evolution of corambid nudibranchs (Mollusca: Gastropoda). Zoological Journal of the Linnean Society, 163, 585-604. https://doi.org/ 10.1111/j.1096-3642.2011.00720.x

McDonald, G. R. (1983). A review of the nudibranchs of the California coast. Malacologia, 24(1-2), 114-276.

Miller, M. C. (1958). Studies on the nudibranchiate Mollusca of the Isle of Man. PhD Thesis, University of Liverpool.

Millen, S. V., \& Martynov, A. V. (2005). Redescriptions of the nudibranch genera Akiodoris Bergh, 1879 and Armodoris Minichev, 1972 (Suborder Doridacea), with a new species of Akiodoris and a new family Akiodorididae. Proceedings of the California Academy of Science, 56, 1-22.

Moles, J., Wägele, H., Uhl, G., \& Avila, C. (2017). Bipolarity in sea slugs: A new species of Doridunculus (Mollusca: Nudibranchia: Onchidoridoidea) from Antarctica. Organisms Diversity \& Evolution, 17(1), 101-109. https://doi.org/10.1007/ s13127-016-0309-z

MolluscaBase eds. (2021). MolluscaBase. Goniodorididae H. Adams \& A. Adams, 1854. Accessed through: World Register of Marine Species at: http://www.marinespecies.org/aphia. $\mathrm{php} ? \mathrm{p}=$ taxdetails $\& \mathrm{id}=174$ on $2021-02-23$.

Montagu. G. (1808). Supplement to Testacea Britannica with additional plates. Woolmer, Exeter. v $+183 \mathrm{pp}$.

Nakano, R. (2018). Field guide to sea slugs and nudibranchs of Japan. Bun-ichi Co.

Naya-Garmendia, L. M. (2016). Nudibranquios de la costa vasca. El pequeño Cantábrico multicolor. Ed. Aquarium de DonostiaSan Sebastián.

Neubauer, T. A., van de Velde, S., Yanina, T., \& Wesselingh, F. P. (2018). A late Pleistocene gastropod fauna from the northern Caspian Sea with implications for Pontocaspian gastropod taxonomy. ZooKeys, 770, 43. https://doi.org/10.3897/zooke ys. 770.25365

Nobre, A. (1932). Moluscos Marinhos de Portugal. Universidade Porto.

Ortea, J., Moro, L., Bacallado, J. J., \& Caballer, M. (2014). Nuevas especies y primeras citas de babosas marinas (Mollusca: Opisthobranchia) en las islas Canarias y en otros archipiélagos de la Macaronesia. Vieraea, 42, 47-77

Ortea, J., Quero, A., Rodríguez, G., \& Valdés, Á. (1989). Redescripción de Trapania tartanella (Ihering, 1986) (Mollusca: Nudibranchia). Bollettino Malacologico, 25(5-8), 241-246.

Padula, V., Araujo, A. K., Matthews-Cascon, H., \& Schrödl, M. (2014). Is the Mediterranean nudibranch Cratena peregrina (Gmelin, 1791) present on the Brazilian coast? Integrative species delimitation and description of Cratena minor n. sp. Journal of Molluscan Studies, 80(5), 575-584. https://doi.org/10.1093/mollus/ eyu052

Palmer, B. A., Taylor, G. J., Brumfeld, V., Gur, D., Shemesh, M., Elad, N., Osherov, A., Oron, D., Weiner, S., \& Addadi, L. (2017). The 
image-forming mirror in the eye of the scallop. Science, 358, 1172-1175. https://doi.org/10.1126/science.aam9506

Pante, E., Schoelinck, C., \& Puillandre, N. (2015). From integrative taxonomy to species description: one step beyond. Systematic Biology, 64(1), 152-160.

Paz-Sedano, S., Ortigosa, D., \& Pola, M. (2017). A new Okenia Menke, 1830 from the Azores Islands, Portugal (Mollusca, Nudibranchia, Goniodorididae). Spixiana, 40(1), 13-22.

Paz-Sedano, S., Candás, M., Gosliner, T. M., \& Pola, M. (2021). Undressing Lophodoris danielsseni (Friele \& Hansen, 1878) (Nudibranchia: Goniodorididae). Organimsm Biodiversity and Evolution. https://doi.org/10.1007/s13127-020-00470-z

Penney, B. K., Ehresmann, K. R., Jordan, K. J., \& Rufo, G. (2018). Micro-computed tomography of spicule networks in three genera of dorid sea-slugs (Gastropoda: Nudipleura: Doridina) shows patterns of phylogenetic significance. Acta Zoologica, 101(1), 5-23. https://doi.org/10.1111/azo.12266

Philippi, R. A. (1841). Zoologische Bemerkungen. Archiv Für Naturgeschichte, 7(1), 42-59.

Philippi, R. A. (1844). Enumeratio molluscorum Siciliae cum viventium tum in tellure tertiaria fossilium, quae in itinere suo observavit. (Vol. 2). Halle [Halis Saxorum]: Eduard Anton. iv +303 .

Pires, A. C., \& Marinoni, L. (2010). DNA barcoding and traditional taxonomy unified through Integrative Taxonomy: A view that challenges the debate questioning both methodologies. Biota Neotropica, 10(2), 339-346.

Pola, M. (2015). The identity of Okenia zoobotryon (Smallwood, 1910) (Nudibranchia: Goniodorididae): Redescription and proposed designation of a neotype. American Malacological Bulletin, 33(1), 72-77. https://doi.org/10.4003/006.033.0101

Pola, M., Roldan, P., \& Padilla, S. (2014). Molecular data on the genus Okenia (Nudibranchia: Goniodorididae) reveal a new cryptic species from New South Wales (Australia). Journal of the Marine Biological Association of the United Kingdom, 94(3), 587-598. https://doi.org/10.1017/S0025315413001793

Pola, M., Paz-Sedano, S., Macali, A., Minchin, D., Marchini, A., Vitale, F., Licchelli, C., \& Crocetta, F. (2019). What is really out there? Review of the genus Okenia Menke, 1830 (Nudibranchia: Goniodorididae) in the Mediterranean Sea with description of two new species. PLoS ONE, 14(5), e0215037. https://doi.org/ 10.1371/journal.pone.0215037

Pruvot-Fol, A. (1933). Mission Robert Ph. Dollfus en Égypte. Opisthobranchiata. Mémoires de l'Institut d'Egypte, 21, 89:159.

Pruvot-Fol, A. (1931). Note systematique sur Ies Opisthobranches. Bulletin Du Muséum National D'histoire Naturelle Du Paris, 2(3), 308-316.

Pruvot-Fol, A. (1954). Mollusques Opisthobranches, Faune de France 58.

Risbec, J. (1928). Contribution a l'etude des nudibranches Néo-Calédoniens. Thèse présentée à la faculté des sciences de l'Université de Paris pour obtenir le grade de docteur ès-sciences naturelles. Faune des Colonies Française, 2(1), 1-328.

Risso, A. (1818). Mémoire sur quelques Gastropodes nouveaux, Nudibranches et Tectibranches observés dans la mer de Nice. Journal De Physique, De Chimie, D'histoire Naturelle Et Des Arts, 87, 368-377.

Rudman, W. B. (1987). The genus Trapania (Nudibranchia: Goniodorididae) in the Indo-West Pacific. Journal of Molluscan Studies, 53(2), 189-212. https://doi.org/10.1093/mollus/53.2.189

Rudman, W. B. (1998). Opisthobranchia: History of discovery, and order Nudibranchia. Pp. 919-921, 990-1017 in: Beesley, P.L., Ross, G.J.B. \& Wells, A. (eds), Mollusca: The southern synthesis. Fauna of Australia. Volume 5. CSIRO: Melbourne.

Rudman, W. B. (2004). Further species of the opisthobranch genus Okenia (Nudibranchia: Goniodorididae) from the Indo-west Pacific. Zootaxa, 695, 1-70.
Rudman, W. B. (2007). Two new species of Okenia (Gastropoda: Nudibranchia: Goniodorididae) from eastern Australia and Tanzania. Zootaxa, 1657(1), 57-67. https://doi.org/10.11646/zootaxa. 1657.1.4

Rudman, W. B., \& Darwell, B. W. (1990). Opisthobranch molluscs of Hong Kong: Part 1. Goniodorididae, Onchidorididae, Triophidae, Gymnodorididae, Chromodorididae (Nudibranchia). Asian Marine Biology, 7, 31-79.

Sales, L., Migotto, A. E., Baroni, S., \& Cunha, C. M. (2019). Taxonomic reassessment and redescription of Okenia polycerelloides (Ortea \& Bouchet, 1983) (Nudibranchia: Goniodorididae) based on morphological and molecular data. Marine Biodiversity, 49(5), 2351-2368. https://doi.org/10.1007/s12526-019-00972-w

Sars, G. O. (1878). Bidrag til kundskaben om norges arktiske fauna: I. Mollusca regionis arcticae norvegiae. Oversigt over de i norges arktiske region forekommende blřddyr. Brr̆gger.

Schillo, D., Wipfler, B., Undap, N., Papu, A., Boehringer, N., Eisenbarth, J. H., Kaligis, F., Bara, R., Schäberle, T. F., König, G. M., \& Waegele, H. (2019). Description of a new Moridilla species from North Sulawesi, Indonesia (Mollusca: Nudibranchia: Aeolidioidea)-Based on MicroCT, histological and molecular analyses. Zootaxa, 4652(2), 265-295. https://doi.org/10.11646/zootaxa.4652.2.3

Schlick-Steiner, B. C., Arthofer, W., \& Include: Steiner, F. M. (2014). Take up the challenge! Opportunities for evolution research from resolving conflict in integrative taxonomy. Molecular Ecology, 23, 4192-4194.

Schmekel, L. (1968). Ascoglossa, Notaspidea und Nudibranchia im litoral des Golfes von Neapel. Revue Suisse De Zoologie, 75(6), 103-155.

Sigurdsson, J. B. (1991). A nudibranch, Murphydoris singaporensis, new genus and species, from Singapore mangroves (Mollusca: Opisthobranchia: Goniodorididae). Raffles Bulletin of Zoology, 39, 259-263.

Sigwart, J. D., Lindberg, \& D. R. (2015). Consensus and confusion in molluscan trees: Evaluating morphological and molecular phylogenies. Systematic Biology, 64, 384-395. https://doi.org/ 10.1093/sysbio/syu 105

Stimpson, W. (1853). Synopsis of the marine Invertebrata of Grand Manan: Or the region about the mouth of the Bay of Fundy, New Brunswick. Smithsonian Contributions to Knowledge, 6, 1-66.

Su, Y., Huang, L. J., Chang, Y. W., \& Mok, H. K. (2009). Temporal changes in nudibranch composition at a coast site off Penghu (the Pescadores) in the Taiwan strait. Zoological Studies, 48(4), $448-459$.

Swennen, C., \& Buatip, S. (2012). Murphydoris singaporensis (Gastropoda: Nudibranchia: Goniodorididae) found in Thailand; with external and first internal description of the specimens. Strombus, 19(1-2), 9-14.

Tautz, D., Arctander, P., Minelli, A., Thomas, R. H., \& Vogler, A. P. (2003). A plea for DNA taxonomy. Trends in Ecology and Evolution, 18, 70-74. https://doi.org/10.1016/S0169-5347(02)00041-1

Thompson, W. (1840). Contributions towards a knowledge of the Mollusca Nudibranchia and Mollusca Tunicata of Ireland, with descriptions of some apparently new species of Invertebrata. Annals of Natural History, 5, 84-102.

Thompson, T. E., \& Brown, G. H. (1984). Biology of opisthobranch molluscs. (vol. 2). 229 pp., 41 pls. Ray Society, no. 156.

Urgorri, V., \& Besteiro, C. (1983). A checklist of the opisthobranch mollusks from Galicia. Investigación Pesquera, 47(1), 3-28.

Valdés, Á., \& Bouchet, P. (1998). A blind abyssal Corambidae (Mollusca, Nudibranchia) from the Norwegian Sea, with a reevaluation of the systematics of the family. Sarsia, 83, 15-20. https:// doi.org/10.1080/00364827.1998.10413665

Vayssière, A. (1901). Recherches zoologiques et anatomiques sur les mollusques Opistobranches du Golfe de Marseille (suite et 
fin). Memoire No. 1. Marseille: Annales du Musee d'Histoire Naturelle de Marseille (Zoologie), 6, 1-130, pls. 1-7.

Vayssière, A. (1913). Mollusques de la France et des régions voisines, tome premier, amphineures, gasteropodes opisthobranches, heteropodes, marseniades et oncidiides. Encyclopedie Scientifique, publiee sous la direction du Dr. Toulouse, Bibliotheque de Zoologie Doin. Paris.

Vayssière, A. (1919). Recherches zoologiques et anatomiques sur les Mollusques Opisthobranches du Golfe de Marseille, 2me Supplément. Annales Du Musee D'histoire Naturelle De Marseille, $17,53-92$.

Wägele, H., \& Cervera, J. L. (2001). Histological study of Goniodoris castanea Alder and Hancock, 1845 (Nudibranchia, Doridoidea, Goniodorididae). Journal of Morphology, 250(1), 61-69.

Waterton, C., Ellis, R., \& Wynne, B. (2013). Barcoding nature: shifting cultures of taxonomy in an age of biodiversity loss. Routledge.

Wheeler, Q. (2013). Are reports of the death of taxonomy an exaggeration? New Phytologist, 201(2), 370-371.

Willan, R. C., \& Coleman, N. (1984). Nudibranchs of Australia. Australian Marine Photographic Index.
Xavier, J. C., Allcock, S. L., Cherel, Y., Lipinski, M. R., Pierce, G. J., Rodhouse, P. G. K., Rosa, R., Shea, E. K., Strugnell, J. M., Vidal, E. A. G., Villanueva, R., \& Ziegler, A. (2015). Future challenges in cephalopod research. Journal of the Marine Biological Association of the United Kingdom, 95, 999-1015. https://doi.org/10.1017/ S0025315414000782

Ziegler, A., Bock, C., Ketten, D. R., Mair, R. W., Mueller, S., Nagelmann, N., Pracht, E. F., \& Schröder, L. (2018). Digital three-dimensional imaging techniques provide new analytical pathways for malacological research. American Malacological Bulletin, 36(2), 248-274. https://doi.org/10.4003/006.036.0205

Publisher's Note Springer Nature remains neutral with regard to jurisdictional claims in published maps and institutional affiliations. 